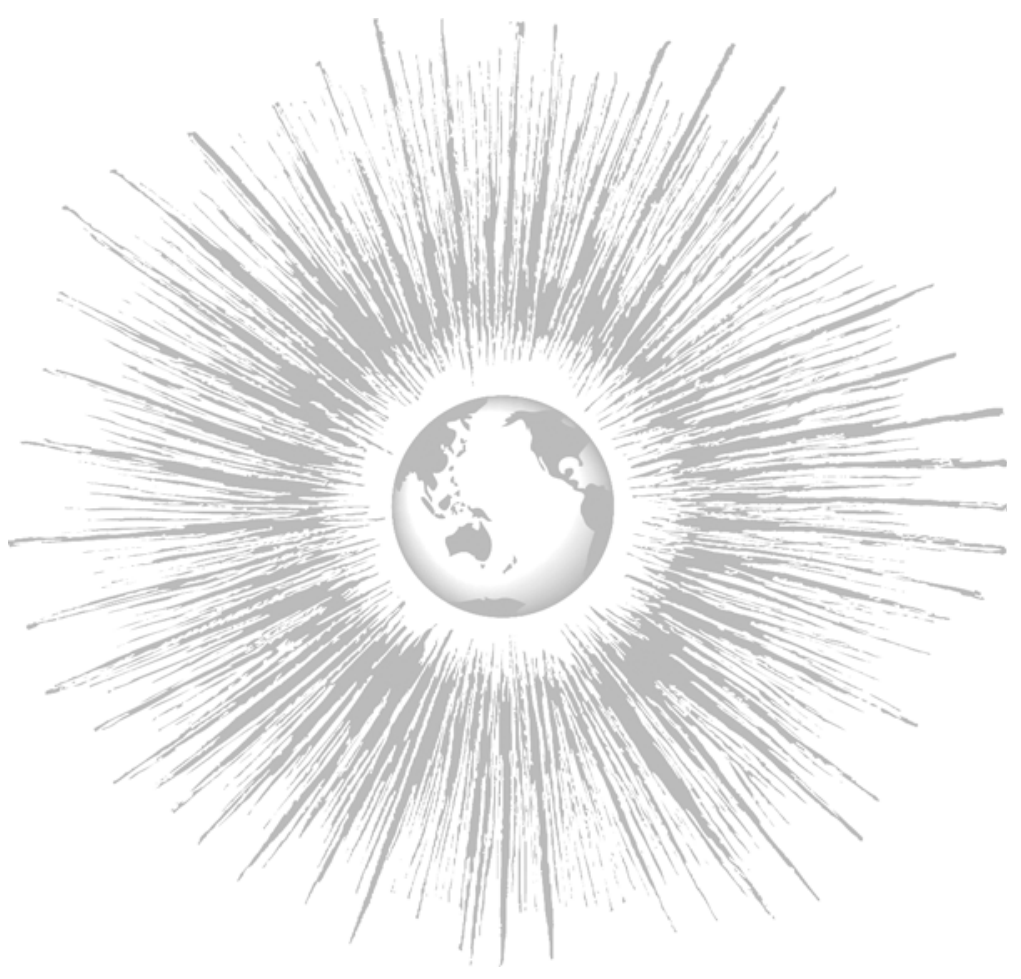

ABSTRACT:

The Calumet \& Hecla Copper Company was a firm funded by core capital, but operating in an internal periphery (Michigan's Upper Peninsula), and eventually subject to peripheral constraints, along with the constraints of the physical environment, the physical characteristics of copper, and a concentrating industrial structure itself due largely to the physical characteristics of othe types of copper mined elsewhere in the world. I focus on the firm's efforts to maintain market access in the face of both a restructuring copper industry, driven by the coming online of much larger, lower-grade deposits that required much larger aggregations of capital to extract and process; and a restructuring transport system, driven by copper's industrial restructuring, but also by the politics of those resources.
The Political Economy of Raw Materials Transport from Internal Periphery to Core in the Early 20th Century US: The Calumet \& Hecla Copper Company's Struggle for Market Access, 1922-39

Jonathan Leitner

$\mathrm{T}$ he physical characteristics of a raw material are a salient concern for extractive enterprises (indeed, for nature-based industries in general; see Boyd et al 200I), since the pertinent technologies of extraction, processing and transport are at least somewhat influenced by the physical characteristics of the resources involved (Warriner 1988:497; Schmitz 2000:77). We can also trace the political economies of extractive regions and industries back to the physical characteristics of natural resources (Bunker 1992), a general consideration that is now receiving increasing attention among a subset of world-systems scholars concerned with both the peripheral impacts of natural resource extraction and the importance of resource access for core ascent (e.g. Barham et al 1994; Bunker 1994, 1996; Ciccantell 1994; Dunaway 1996b; Leitner 2003), as well as being recognized as a key to how certain sectors of the world-economy are structured (e.g. Leitner 200I; more generally Boyd et al 200I), and perhaps even how the world-economy as a whole is structured (Ciccantell and Bunker 2002:63-70).

In a related vein, resource transport from periphery to core has also received some recent attention in the world-systems literature, with works over the past decade exploring transport's importance to capitalism's historical development, through increasing the speed and scope of circulation, improving access to raw materials, and being a leading sector for rising hegemons, in part due to the ever-increasing need for raw materials entailed by economic ascent (Hugill 1993; Ciccantell and Bunker 1998a, 2002; Bunker and Ciccantell 1995b, 1999; Bunker 1996, 2003; Ciccantell 200I:60-64). In the specific case of the United States, Bunker and Ciccantell (1995b:112; 1999:109, I15-16) posit that its core emergence

\section{Jonathan Leitner}

j_leitner@yahoo.com gence and eventual hegemonic ascendance, which was largely based on its domestic raw materials and the internal transport lines that enabled core industry to gain cheap access to
JOURNAL OF WORLD-SYSTEMS RESEARCH, X, 2, SUMMER 2004, 397-435 bttp://jwsr.ucr.edu/

ISSN $1076-156 \mathrm{X}$

(C) 2004 Jonathan Leitner 
and hegemonic ascendance was largely based on its domestic raw materials and the internal transport lines, chiefly rail but also water, that enabled core industry to gain cheap access to those resources ( $c f$. Arrighi 1999:228). This paper examines a part of that process, through the experience of the Calumet \& Hecla Copper Company-a firm funded by core capital, but operating in an internal periphery (Michigan's Upper Peninsula), and eventually subject to peripheral constraints, along with the constraints of the physical environment and the physical characteristics of the commodity it extracted and processed, and a concentrating industrial structure due in large part to the physical characteristics of the copper its competitors mined elsewhere in the world. In particular, I examine the firm's efforts to maintain market access in the face of both this restructuring industry and a restructuring transport system: the former driven by the coming on-line of much larger, lower-grade deposits that required much larger aggregations of capital to extract and process (Schmitz 1986, 1997, 2000); the latter driven by the former, but also by the politics of core and periphery within the U.S., including the imperatives of transport capital that tied peripheral resources to core manufacturing industry.

I should first address two caveats, however. One methodological: without falling back on a sort of methodological individualism, correspondence between corporate managers can provide an important data source for the decisionmaking process within firms, one that I rely on heavily here. Another metatheoretical: granted, studying a given firm within the context of the world-system, or more specifically the world-economy, can be problematic. Wallerstein (1991:43) warns that the study of core-periphery relations at the sub-nation-state level risks "edg[ing] ourselves towards an asymptote where, once we arrive at the level of individual enterprises, we have lost almost all significant spatial reference." And the game may not be worth the candle: Ciccantell (1994:53) comments that the world-systems perspective "offers only limited insights" about the roles that firms play as "social actors" in the world-economy.

Yet Chase-Dunn (1989:310) argues that "some world-system processes must be studied by examining smaller units of analysis such as nation states or transnational firms" (his italics). De Oliver (1995:567) asserts that the transnational corporation has been "the principal vector for carrying capital from the core to the periphery-and just as important, directing it within the periphery" (also see Barham et al 1994). We should add that the firm in question does not necessarily have to be a transnational operator, when we recognize the world-system is nested (Chase-Dunn 1989:209-IO), and that internal peripheries exist, even within otherwise core nation-states like the United States (see, e.g. Bensel I984; Agnew 1987; Dunaway 1996a; Beaman and Hraba 1991; Hanna 1995; Robbins 1994; Billings and Blee 2000). Further, studying the politics of core and periph- ery in these smaller units allows us to gain a finer-grained understanding of the politics of the world-economy by seeing how they play out on the ground.

\section{CALUMET \& HECLA'S TRANSPORT BINDः GETTING COPPER TO CORE} CUSTOMERS COMPETITIVELY

The element of transportation in this highly competitive era enters so materially into the delivered cost of the supplies we purchase, and the delivered cost of the commodity we sell, that we must be ever alert to changes in rate bases affecting either our inbound or outbound traffic.

-J.J. Mechlin to James MacNaughton

(18 August 1933, C\&H/Box 74/Folder 44)

The traffic manager of the Calumet $\&$ Hecla Consolidated Copper Company $(\mathrm{C} \& \mathrm{H})$ made the above comment to the company president in the depths of the Great Depression. C\&H was still the most prominent firm in the Upper Peninsula (U.P.) of Michigan's copper region (the "Copper Country"; see Maps I-2), producing over 4.6 million pounds of raw copper during $1867-1946$, or nearly 49 percent of the regional industry's total (Gates 1951:230). During the I870s, Michigan producers, led by $\mathrm{C} \& \mathrm{H}$, held a nearly monopolistic position in the U.S. (Whitten 1983:169). Western U.S. copper deposits were soon discovered however, and Michigan producers were dwarfed by western U.S. producers in the early I90os; by the I920s the Copper Country's stature had shrunk considerably, dropping from well over 80 percent of U.S. smelter copper production in the I870s, down to under Io percent in 1923 (see Chart I).

By the early 1930s, copper's price was at all-time lows, which made transport costs proportionately much higher. For North American mining districts-or any mining district - the "element of transportation" has always been important; "most of the major coal and metals mining districts [in North America] could never have developed without their railways" (Francaviglia 1991:73; also see Paul 1963). In upper Michigan's Copper Country however, lake transport was just as important as rail (at least when the lakes weren't frozen), and in fact had been the only option for several decades before the district's connection to the continental railnet in the early I880s. Water transport during navigation season was a practical necessity for very cheap (yet often very important) bulk goods, above all coal: in 1926, over 40 years after the Copper Country received an external rail link in $1883, \mathrm{C} \& H$ 's president wrote the firm's chairman, "the freight on any coal shipped in here by rail would make its use prohibitive" (James MacNaughton to R.L. Agassiz, I2 November 1926, C\&H/175/13). In comparison, outbound copper had a high enough value to pay its rail freight (see Chart 2). 
Map 1 - The Great Lakes of North America

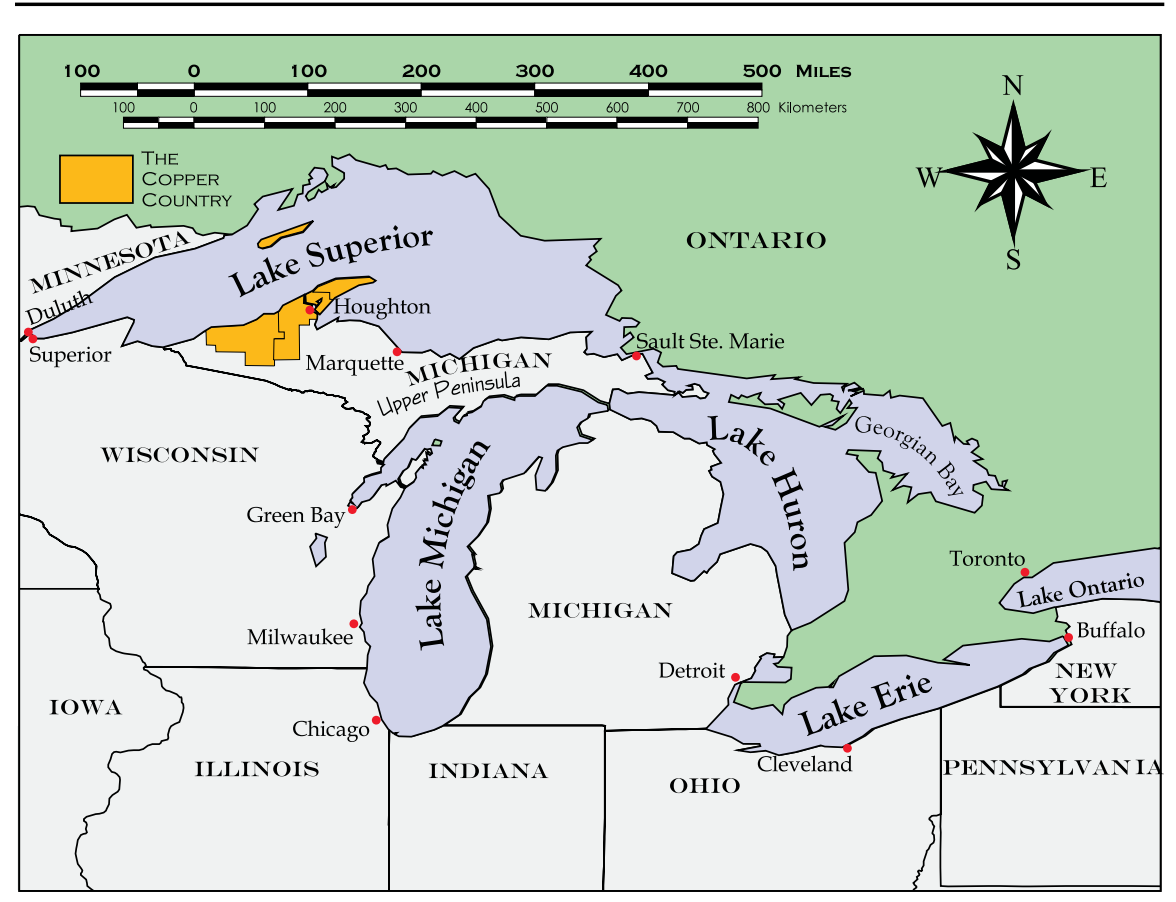

Having multiple transport options for at least part of the year also provided an important control on the freight rates charged to extractive capital: during the Great Lakes' navigation season, usually May-December, competition from cheaper lake shipping forced railroads to keep their prices down (Barry 1973; Thompson 199I), especially when combined ownership of railroads and lake shippers was prohibited in 1915 (Kennedy 1991:148-49; EMJ 1915). However, when the lakes froze in winter, railroads serving Michigan's Upper Peninsula (U.P.) would raise their rates. This practice became a serious point of contention in the IgIos, when Detroit and Chicago manufacturers supplied by U.P.mined copper inputs lodged two complaints with the Interstate Commerce Commission (ICC). In both cases, the ICC ruled the railroads had a right to charge seasonally-variable rates, due to the relative lack of other goods shipped from the Copper Country, and copper's relatively high value (ICC 1913a:357-63, I913b:415-16). Not just a regulator of transport capital, the ICC would become even more of an institutional mechanism of core-periphery economic relations following the 1920 Federal Transportation Act (Skowronek 1982:282-83). In the wake of that legislation (which followed a period of federal control over the railroads that oriented the ICC to the prerogatives of railroad capital; Hoogen-
Map 2 - The Copper Country's Main Ports

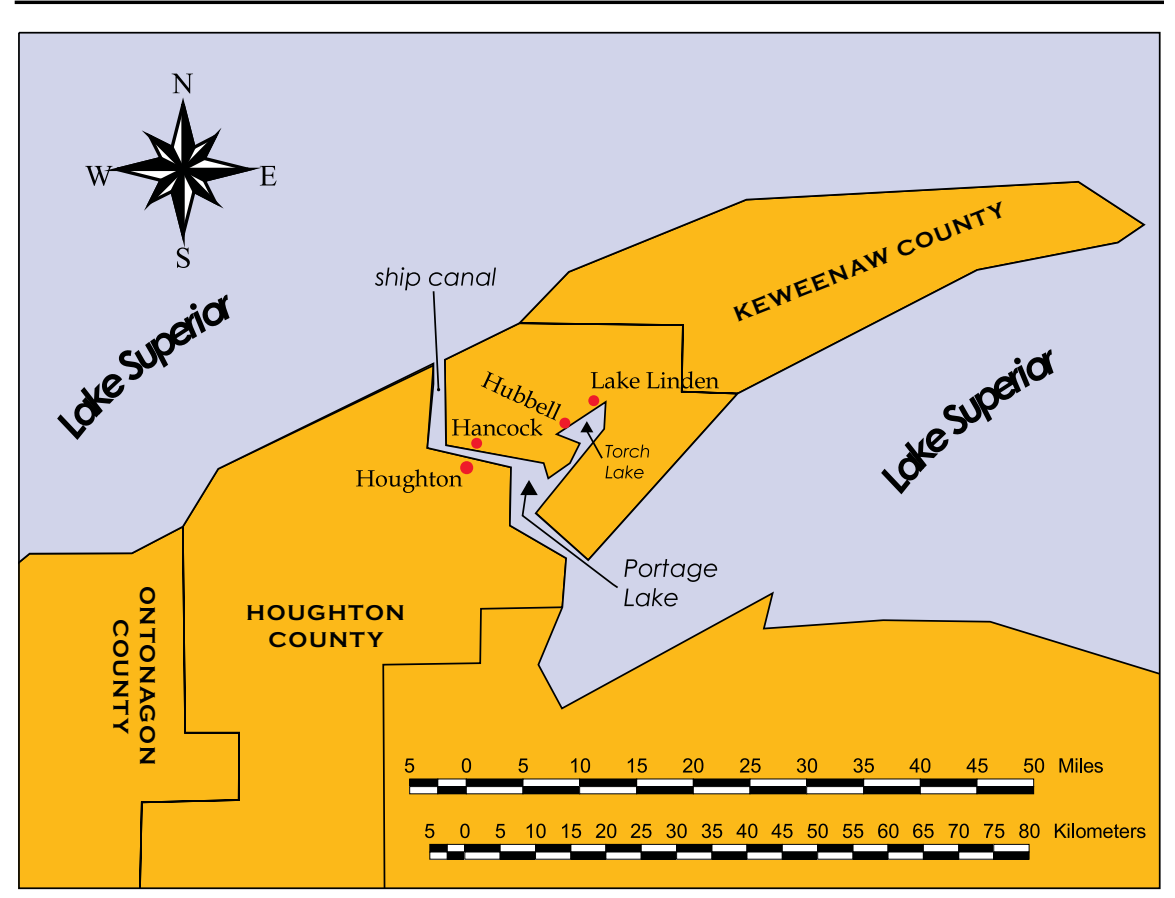

boom and Hoogenboom 1976:84-94), the ICC became more inclined to accede to the railroads' prerogative to charge higher rates based on the "value-of-service," i.e. charges were based on the value of the goods being shipped. For the railroads, this was a long-standing practice, entailing the cheaper shipment of unprocessed raw materials than manufactured goods over longer distances, "causing manufacturers to locate factories away from raw materials" (Hoogenboom and Hoogenboom 1976:55-56), hence a mechanism of regional underdevelopment within the U.S., since it provided economic justification to ship unprocessed raw materials from peripheral extractive regions to core regions (also Pred 1965:172).

The ICC's basic reasoning did not bode well for C\&H's own later efforts to secure lower freight rates. The practice of setting rates according to value of service (or what the traffic will bear) rather than the cost of service meant in reality that the higher a commodity's value relative to its volume, the higher the freight rate charged, because transportation made up a lower proportion of the commodity's eventual cost (McPherson 1912:222, 23I; Ripley 1923:166, I6971; Hoogenboom and Hoogenboom 1976:102). Allowing railroads to profit in this way was a means to promote their growth, which helped tie the U.S. core 
Chart 1 - Share of U.S. Smelter Copper Output, 1870-1940

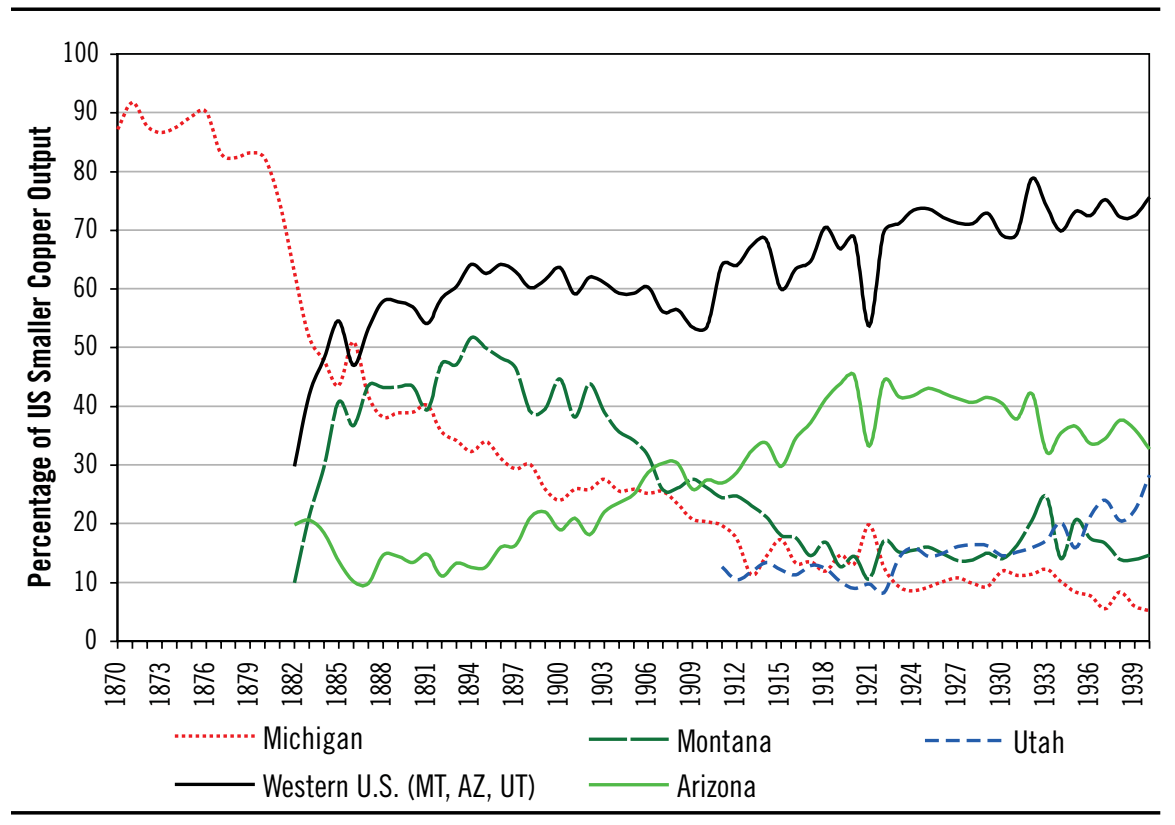

Sources: Gates I95I: 204-05; Weed I912: 23, I917: 152, 1923: I6I; Rothwell; I893: 109, I897: 202-03, I900: 158; Newland 1904: 74; Fay I9II: I49; Johnson 1929: 132; Barbour 1935: 12I, 194I: 136.

regions to the internal peripheries, one of the keys to the initial U.S. ascent up the world-system hierarchy (Bunker and Ciccantell I999:I09, II6). The arrangement also kept transport costs low for raw materials, which in turn ultimately let U.S. industry keep its prices down (in part because cheap transport also allowed cheaper food supplies for urban industrial workers, hence lower wages), which is of course a key aspect of competitiveness in the world-economy, especially for aspiring ascendants (Bunker and Ciccantell 1999:108; Chase-Dunn 1989:174; Ciccantell and Bunker 1998b:7). It is also true, however, that not all firms, sectors, or regions will benefit by such arrangements. It worked well enough for $\mathrm{C} \& \mathrm{H}$ until the early decades of the $20^{\text {th }}$ century. At that point, the firm's production began declining relative to the massive output of its western competitors, who could provide the necessary tonnage to the railroads, satisfying the imperatives of transport capital to fully utilize its rolling stock in bringing peripheral resources a longer distance to the U.S. core region, that "belt of country aligned more or less along a New York City-Chicago axis" (Meinig 1978:1198), as well as Boston to Baltimore-and this at a time when the U.S. state was pursuing autarchic policies as the liberal world trading order decayed,
Chart 2 - Freight Rates for Water Transportation of Coal and Copper Between Lake Superior and Lower Lake Ports

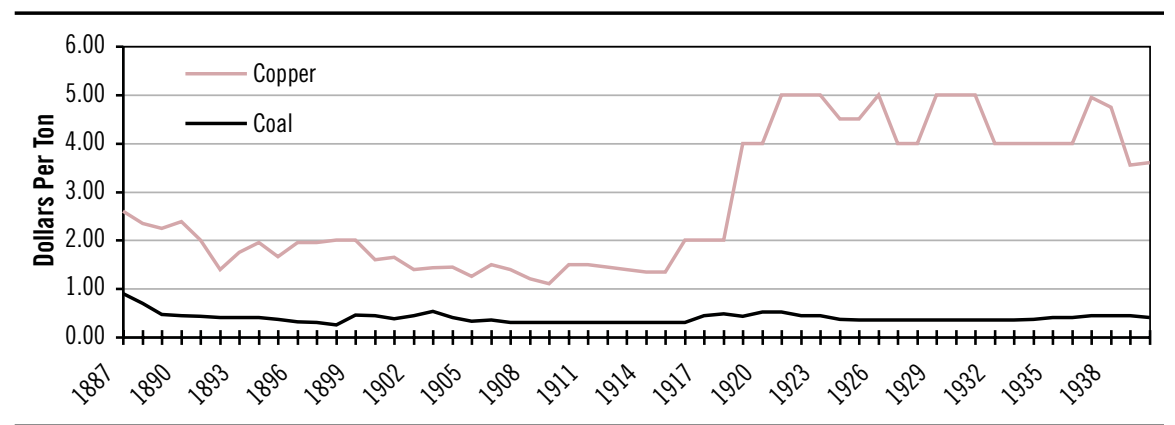

Source: Gates 1951: 231

entailing both a sort of proto-imperial expansion ( $\mathrm{Su} 2001: 44-47)$ and a need to maximize resource extraction from internal peripheries.

Indeed, at least up until World War One the U.S. copper market was essentially "self-contained," thanks to very large internal supplies relative to demand (Schmitz 1997:314). Though having acquired several of its smaller competitors in 1924, and still the Copper Country's largest firm in the I920s, $\mathrm{C} \& \mathrm{H}$ had nonetheless long since dropped from the ranks of the U.S.'s leading copper producers. While the firm prospered during the mid-ig2os after difficult post-war years (Gates 1951:150; Benedict 1952:194-99), its production costs had become high enough to impel the firm's managers to secure the lowest possible freight rates for its copper, at least relative to domestic competitors. These efforts actually began in the early 1920s, with $\mathrm{C} \& \mathrm{H}$ attempting to cajole the various regional freight committees-established by the railroads as a means of self-regulation-into rate reductions. The firm also petitioned Michigan's Public Utilities Commission, and repeatedly threatened to bring the matter before the ICC. ${ }^{1}$

1. See various correspondence between: $\mathrm{C} \& \mathrm{H}$ vice president/general manager James MacNaughton and C\&H president R.L. Agassiz, August I922-June 1924, C\&H I985/20409/I; C\&H traffic manager J.J. Mechlin and Mineral Range Railroad Co. Traffic Manager S.R. Lewis, November I922-December 1923, and Mechlin to C\&H headquarters in Boston, 8 March 1924, C\&H/7I/40; Mechlin and MacNaughton, January I923-June I924 in C\&H/7I/40, and January I925-December I927 in C\&H/72/28b; Mechlin to Standing Rate Committee, Western Trunk Lines, 28 August I926 and Chicago \& Northwestern Railroad traffic manager R.C. Kew to Mechlin, 2I December I926, C\&H/72/28b. 
After several years, $\mathrm{C} \& \mathrm{H}$ had moderate success in getting lower rates, but these victories proved temporary in light of larger changes in the copper industry and that industry's changing relationship to the railroads during the late I920s-30s. C\&H's later haggling over freight rates with the railroads and lake carriers became part of a larger struggle for market access, as its competitors in the U.S. copper industry transformed themselves into large, integrated, multinational firms. Though this was of course part of a more general evolution of U.S. industrial capitalism and the trend of U.S. ascent toward hegemony in the early twentieth century (Arrighi 1999:228-29; Dowd 1977:230-3I), this particular movement was also strongly prompted by the low grade but very large porphyry copper deposits of the southwestern U.S. and northern Chile, which required much larger aggregations of capital to exploit, leading to much larger copper producing firms than previously (Schmitz 1986:399-406, 2000:85-90). Again, in turn within the U.S., the railroads were more likely to offer these very large copper producers comparatively better freight rates than were offered $\mathrm{C} \& \mathrm{H}$. C\&H management was compelled to fight for lower freight rates, but was up against geologically- and technologically-influenced structural change in the U.S. (and generally world) copper industry, which in turn caused changes in copper's North American transport structure to the firm's detriment.

\section{"THE LAKE COMPANIES MAY WELL VIEW THE SITUATION WITH} ALARM": CONSOLIDATION AND VERTICAL INTEGRATION AMONG U.S. COPPER PRODUCERS, $1922-1927$

By the mid-rg2os, U.S.-based firms were the world-economy's leading copper producers. Prompted by growing demand from a burgeoning electrical industry, U.S. copper firms had passed their Chilean counterparts for the lead in raw copper production, mining half the world's copper from domestic mines by the mid-I89os. United States-based producers cemented their dominance following Swansea's rapid post-190o decline; by World War One, the U.S. served as the Allies' main copper supplier (Richter 1923:200; Schmitz 1986:394; Newell 1990:92; Morse 1918:74-75; Pettengill 1935:433).

Yet upper Michigan's Copper Country was a relatively minor player by this point, comprising "the most marginal" sector of the U.S. copper industry, if not the world (Strauss 193I). Copper Country production lagged behind the western U.S., and its relative costs were rising (Gates I95I:I2I; see Chart I). In $1916 \mathrm{C} \& \mathrm{H}$, which also served as smelter and selling agent for several other Michigan producers, sold $\mathrm{I} 60$ million pounds of refined copper, basically the same amount sold by L. Vogelstein \& Co., an independent dealer. The leading dealers all served firms that mined the massive southwestern U.S. and Andean porphyry deposits, led by the American Smelting \& Refining Co. (ASARCO)
The Political Economy of Raw Materials Transport

with I,046 million pounds sold, followed by United Metals Selling Co. (597 million), Phelps, Dodge \& Co. (247 million), and American Metal Co. (I69 million). Combined with the 94 million pounds sold by the other Copper Country firms not under C\&H's umbrella, the 254 million pound total still left the Copper Country a distant third to the multinationals ASARCO and United Metals (Richter 1923:200; Weed I917:160).

U.S. copper production was repeating some of the British producers' experience in the $19^{\text {th }}$ century, with sources of supply moving outward from the home country, along with certain phases of ore processing (Newell 1990; Leitner 200I:38I-98), because it was more economical to reduce bulk closer to the mine, especially with the large, lower grade porphyry deposits of the southwestern U.S. and Chile (Schmitz 1986:403, 1997:313; Bunker 1994:442). From the perspective of the individual firms, the size and low mineral grade of a typical porphyry orebody entailed very large capital investments over a long time period. Porphyries were worked as either open-cut "strip mines" or through block caving, which used explosives to break up ore underground; "[ $t]$ he net effect of both these [techniques] was to replace selective by non-selective methods of mining, in which all material in the mineralized area was removed, waste as well as metallic ore," which also encouraged smelting to reduce bulk, just as well given porphyry deposits' usually extreme remoteness (Schmitz 1986:40304, also 2000:85-90; and see Parsons 1933).

Porphyry mining's capital requirements helped make the other major U.S. copper firms - among them Anaconda, Kennecott, Phelps-Dodge, and ASARCO_even larger and more powerful compared to the Michigan firms, led by C\&H. Further, within the U.S., the large amounts of mineral produced at the mines, and metal at the smelters, provided the financially strapped western U.S. railroads with lucrative ton-miles. In turn, they granted the western U.S. firms competitive rates to the midwest and east—rates that $\mathrm{C} \& \mathrm{H}$ management saw as unfairly competitive, allowing the western firms relatively cheaper access to manufacturing customers in eastern and midwestern markets. Increasingly marginalized within the industry, $\mathrm{C} \& \mathrm{H}$ was further losing out to its competitors in more remote peripheral regions, who were better able to meet the imperatives of expanded transport capital in bringing raw materials to the core.

Production in Canada and Africa also increased greatly during the I910s-I930s, leading to global oversupply (Muirragui 1989:77-79; Pettengill 1931:148-5I). Commenting on the massive, low-cost African deposits in the Belgian Congo and Northern Rhodesia just then hitting their productive stride, a mining journalist predicted that low production costs would enable these firms to promote demand by keeping prices low, a "new era into which the copperproducing industry has entered," in which "one may reasonably expect that 
the...low-cost producers will strive to prevent the price going high enough to retard the growth of consumption of the metal" (Walker 1934:247; and see e.g. Gann 1955:6-8). This was not good news for the higher-cost Michigan producers, already dealing with competition from the low-cost porphyry deposits in the southwestern U.S., besides continuing production from Montana.

More immediate problems loomed for $\mathrm{C} \& \mathrm{H}$ and other Michigan producers when the larger western firms began vertically integrating into fabrication. Detroit had become Michigan copper's major market, but several of C\&H's Detroit customers were absorbed by Anaconda and the Guggenheims, and the firm had to focus on Chicago and other "western" consumers. At the same time, while copper prices were generally declining due to global oversupply (Gates 1951:203-06), rail rates in the U.S. began to rise again, particularly on copper: its still relatively high value-to-volume ratio made it an attractive target for regional rate-setting boards, in spite of the metal's declining price.

Earlier rate reductions had prompted Michigan copper firms to market more of their product in the midwest, starting in the early I920s when Detroitbound rates were cut 35 percent. The rate cut and orientation toward midwest markets were apparently driven by Detroit's burgeoning auto industry (Gates I951:150, 264n.30), which "accounted for an increased use of copper" in general (Schmitz 1997:323). C\&H first contracted with the Ford Motor Company in 1925, which by 1928 was using 30,000 pounds a day and 600,000 pounds per month of C\&H's copper (see Agassiz to MacNaughton, 28 November 1924, and MacNaughton's reply, I December 1924, C\&H 1985/20409/I; Felton to MacNaughton, I5 December 1928, C\&H/175/15); by December 1927, "the bulk" of C\&H's midwest sales were to "Henry Ford," transported by Ford's own boats (EMJ 1927b).

Another motivating factor for C\&H's increased midwest marketing was competition from Anaconda and the Guggenheims. ${ }^{2}$ By the mid-I92os, both of these latter firms had become bona fide multinationals, having steadily grown through vertical integration-part of a more general trend in the copper sector since the late $19^{\text {th }}$ century when mining, smelting and fabricating had all been separate sectors (Schmitz 1997:300). The 1920s were in fact an "era of mergers" between U.S. copper producers, as $\mathrm{C} \& \mathrm{H}$ assistant sales agent Thomas

2. Yet Gates (1951:150) writes: "Throughout [the I920s] Calumet and Hecla evidently played the game fairly much according to rules laid down by the giants of the day: Kennecott [i.e, the Guggenheims], Anaconda, and Phelps-Dodge."
Burghardt termed it in a March 1928 memorandum to board chairman R.L. Agassiz. Burghardt marked the era's start in 1922, when Anaconda purchased the American Brass Company, "the entrance of the producer into the fabricating and manufacturing end of the business on an enormous scale" (Burghardt to Agassiz, "Re: Combinations in the Copper Industry," P. I, enclosure with Burghardt to MacNaughton, 23 March 1928, C\&H/175/17). According to another contemporary observer, this purchase "represented the most important instance in the whole history of the American copper industry of vertical integration beyond the stage of production of raw refined copper" (Richter 1923:203).

Up until this point, vertical integration was fairly unknown among U.S. copper producers. Regardless of specific variety, copper's general physical characteristics, namely low bulk and raw homogeneity, dictated against fabrication by producers near the mines. In the words of a copper industry analyst:

It is characteristic of most branches of the non-ferrous metal industries that the producers of the raw material should not engage in fabrication except of rather simple types. Tonnages are so much smaller than in the iron and steel industry that, apart from other technical factors, this circumstance would make the erection of a fabricating plant, except for some simple product like wire, less attractive or desirable than in the steel industry. The extreme homogeneity of raw copper...makes the final stage in the production of raw copper much more of a mass production operation (Richter 1927:715; also see Hildebrand and Mangum 1992:32).

This same homogeneity had kept the U.S. copper market highly competitive (even with small numbers of sellers and buyers) with very few independent dealers in between, and almost all refined copper going directly from producer or sales agent to consumer or manufacturer (Richter 1923:196-98, 210; also see Ingalls igi2).

The continuing wave of mergers and acquisitions saw the Guggenheims follow Anaconda (to which they sold control of the Chile Copper Company) in expanding their sheet milling operation, the Baltimore Copper Smelting \& Rolling Company, into a rod and wire plant in 1923. Independent wire and cable companies engaged in a series of mergers among themselves during the mid-I920s, resulting in the fall 1927 formation of the General Cable Corporation, "a group which is second only to American Brass Company in volume of copper consumption, and in which the Guggenheim interests predominate" (Burghardt to Agassiz, enclosure with Burghardt to MacNaughton, 23 March 1928, C\&H/175/17). Anaconda subsidiary American Brass then absorbed the Detroit Copper \& Brass Rolling Mills, one of the plaintiffs in the I9I2 ICC lawsuit over seasonal copper freight rate differentials (see above); up until its 
absorption, Detroit Copper $\&$ Brass had been one of C\&H's major customers (see Mechlin to MacNaughton, 9 November 1923, C\&H/7I/40). C\&H executives received further bad news when Chicago's two independent wire firms merged: the new firm purchased much of its rod supply from Anaconda, with which it was "said to be on very friendly terms." By 1927, an industry analyst was able to write that " $[t]$ he Anaconda Copper Mining Company is now more fully integrated...than any other organization in the non-ferrous metal industry of the United States" (Richter 1927:693). The following year, Burghardt summed matters for Agassiz:

within the past few years, and particularly last year [1927], we have seen the very cream of the American copper consuming industry, either through acquisition or close working agreements, pass into the control of the two great producing interests-Anaconda and the Guggenheims... The Lake companies may well view the situation with alarm (Burghardt to Agassiz, PP. 2-3, enclosure with Burghardt to MacNaughton, 23 March 1928, C\&H/I75/I7).

In other words, having avoided vertical integration due to copper's general physical characteristics, and aided in this choice by upper Michigan's initial relative remoteness from the U.S. core region (see Lankton 1997) and the firm's reliance on cheap transport, $\mathrm{C} \& \mathrm{H}$ management now found itself in a bind when its competitors-who were even more remote from the main U.S. core regions, but were larger firms due to their own particular geologically-driven capital requirements - started integrating, and then taking over its market. Burghardt warned his superiors:

For our own company, producing as it does over two-thirds of the output of the district, it would seem vitally important to take immediate steps to safeguard our best market, which is the Middle West. For several months past this market has been gradually narrowing, not because of lack of business there, but principally because of the combinations which operate against us. We have already seen Anaconda attempt to dictate the price at which we may sell them copper at Detroit, and on our refusal to meet their views we have seen this business lost to us. It may not be long before General Cable will tell us what price we must sell them copper at Chicago and St. Louis. These three plants can easily account for one-half of our output, and if they should all be lost to us we may be forced far afield to market our full production

(Burghardt to Agassiz, PP. 3-4, enclosure with Burghardt to MacNaughton, 23 March 1928, C\&H/I75/I7).

However, Burghardt argued that going "far afield" was not a viable option. Despite extensive efforts by C\&H earlier in the decade, rail freight rates on eastbound copper had risen significantly, and $\mathrm{C} \& \mathrm{H}$ could not undercut the east coast's electrolytic refineries low enough to offset the relatively high freight rates its own refined copper incurred over those longer distances, thanks to value-of-service pricing. Along with changes in copper's industrial structure came changes in the transport structure, as the railroads re-evaluated the freight rates formerly charged refined copper. Though much closer to the main core regions of the U.S. than its major western competitors, this would actually work against the firm vis à vis the imperatives of railroad capital.

\section{"WE CAN COMPETE IN THE EAST ONLY AT HEAVY COST"ः A CHANGING TRANSPORT STRUCTURE FOR MICHIGAN COPPER, I927-1929}

Indicative of copper's industrial restructuring and changing economic geography, eastern U.S. railroads actually raised their rates on refined copper shipped within the core, from east coast refineries to midwestern manufacturing points. Detroit's rate per Ioo lbs rose from 25 to 31 cents; Pittsburgh's from 25 to 27 cents; Chicago's from 32 to 40 cents; "and similarly to other points," while certain east coast manufacturing points received rate reductions. ${ }^{3}$ As a result, $\mathrm{C} \& \mathrm{H}$ and other upper Michigan producers were compelled to give up most of their eastern customers. According to C\&H's Burghardt: "Our normal market is in the West [i.e. midwest], and we can compete in the East only at heavy cost to ourselves in the matter of freight and price" (Burghardt to Agassiz, 23 March 1928, enclosure with Burghardt to MacNaughton, 23 March 1928, $\mathrm{C} \& \mathrm{H} / \mathrm{I} 75 / \mathrm{r} 7)$, though conversely, high rates in the other direction gave $\mathrm{C} \& \mathrm{H}$ 's midwestern markets some protection from eastern electrolytic refineries.

Indeed, all copper producers faced potentially higher freight rates, despite calls for cooperation between miners, smelters, and railroads, in order for all sides to maintain profitable levels of production (e.g. EMJ 1926). In June 1928, C\&H's Mechlin noted a proposal docketed before the Central Freight Association (CFA) that would eliminate refined copper's special commodity rate "from and to" points in CFA territory (lower Michigan, Ohio, Indiana, most of Illinois, and far western Pennsylvania and New York). Mechlin believed this new proposal was "an entering wedge to raise the rates on copper throughout the entire country," and warned that during C\&H's efforts to achieve lower freight rates earlier in the decade, copper's high value relative to its volume made certain rate setting authorities on the regional freight committees think copper's rates were too low "as compared to the rates on iron and steel... [and] should be

3. At the same time, midwestern firms were allowed to deduct ro cents more $(32.5$ vs. 22.5) than east coast firms, due to "loss of interest on the value of copper in transit" (EMJ I927a). 
higher" (Mechlin to MacNaughton, II June 1928, C\&H/72/76b). Though an important raw material, copper was not as vital to industrial production as iron and coal, nor was it consumed in as great quantities (and would soon be facing competition from aluminum as well). Within the political bloc of U.S. industrial producers, the main bearers of core interest in the U.S. political economy at that point, copper had been one of the junior partners to iron and steel (Leitner 2000:492), but copper certainly did not generate the traffic that those bulkier materials did. Nor, for that matter, did copper's producers (or consumers) have the political clout commensurate with iron and steel's economic importance.

C\&H's lake shipper, the Great Lakes Transit Corporation (GLTC) was also reconsidering the rates it charged for copper. Though $\mathrm{C} \& \mathrm{H}$ had a portfolio investment in the GLTC, it was managed according to the prerogatives of transport capital, regardless of C\&H's imperatives (see Mechlin to GLTC freight traffic manager F.A. Stanley, 27 June $1925, \mathrm{C} \& \mathrm{H} / 72 / 28 \mathrm{~b}$; and minutes of C\&H Board of Directors meetings, I7 April 1922 and I2 April 1923, C\&H 1985/29). During the 1929 navigation season, $\mathrm{C} \& \mathrm{H}$ management began worrying about delays related to GLTC's other commodity freights (see L.J. Brogan, GLTC general agent in Houghton, to Mechlin, 5 July 1929, enclosure with Mechlin to MacNaughton, 8 July 1929, C\&H/73/54), though the GLTC's local Houghton agent confided in Mechlin that his firm "appreciate[s] the volume and regularity of our business and will do what they can to keep us satisfied" (Brogan to Mechlin, 5 July 1929).

Nonetheless, just a month later Mechlin complained to GLTC president J.C. Evans in Buffalo, expressing C\&H's insecurity about copper's place in the larger Great Lakes shipping trade, at the time still very much a major crossroads of the U.S. industrial economy: "We are very much of the opinion that our tonnage is being considered as entirely non-competitive and that competitive tonnage at the head of the Lakes is being given preference over our shipments during this entire present season" (Mechlin to Evans, 8 August 1929, $\mathrm{C} \& \mathrm{H} / 73 / 54)$. Such was the potential catch-22 in transporting a non-bulk, relatively high value commodity, yet one not as valuable as a precious metal: it did not supply the tonnage that lake carriers needed to keep their own equipment in full use, and because it did not have the value of a precious metal, it still could

4. The U.S. Army Corps of Engineers classified copper not as bulk freight, but rather as "package" freight, "such items that are sacked, bundled, cased, or otherwise assembled, and manufactured products handled individually." Accordingly, the GLTC was not actually considered a bulk carrier, but rather a common-carrier package and passenger line, though it was also carrying grain (U.S. Army Corps of Engineers 1937:395-97, 424). not impel a carrier to take it directly to market. ${ }^{4}$ While copper may have been less important than iron and coal to the U.S.'s standing as a core economy (as well as within the Great Lakes' regional transport economy), C\&H was becoming further marginalized within the copper industry as well.

However, any considerations by $\mathrm{C} \& \mathrm{H}$ to move away from lake shipping during the navigation season were likely made with some pause, because the necessity for cheap transport had become greater than ever-losing the Detroit market to Anaconda forced the firm to concentrate on Chicago and downstate Illinois customers (see Burghardt to MacNaughton, 9 March 1927, C\&H/ 176/I). C\&H's Burghardt elaborated on this option in his March 1928 strategy memo (see above). He offered a number of variations, perhaps boldest of which was to "[f]ollow the lead of Anaconda and Guggenheim, and acquire manufacturing facilities of our own." He also suggested more formalized supply arrangements with Chicago-area manufacturers that were already purchasing C\&H's copper; at the other end of the spectrum, he suggested $\mathrm{C} \& \mathrm{H}$ could supply Anaconda's manufacturing subsidiaries in Detroit, Chicago, and St. Louis with fixed tonnages at fixed prices (Burghardt memo to Agassiz, 23 March 1928, enclosure with Burghardt to MacNaughton, 23 March 1928, C\&H/175/17).

Though C\&H board chairman Rodolphe Agassiz was in favor of Burghardt's vertical integration plan in order to insure a guaranteed purchaser (Agassiz to MacNaughton, I8 November 1925, C\&H 1985/20409/I), the firm's president was less sanguine about integration into manufacturing, at least after the 1929 stock market crash. He wrote C\&H sales agent C.C. Felton: "The fabricating plants will buy from their 'relatives' and we shall have a hard time disposing of our product. On the other hand, we have not assurances of enough volumes or enough life to warrant us at this time going into fabricating" (MacNaughton to Felton, 3 May 1930, C\&H/175/15)..$^{5} \mathrm{C} \& \mathrm{H}$ senior management chose to expand their Chicago base, making it the firm's new primary market: by the fourth quarter of 1928,37 percent of C\&H's refined copper rail shipments went to Chicago, with an additional 20 percent going to other Illinois points and St. Louis; less than 15 percent went to Detroit or other lower Michigan points (evidence presented by Michigan Copper Producers before the Interstate Commerce Commission Rate Structure Investigation, Docket 17000, Part I2, NonFerrous Metals, C\&H 1979/35/Item I0oo).

5. $\mathrm{C} \& \mathrm{H}$ finally acquired manufacturing facilities in 1942 , but in Detroit, not the Copper Country (Benedict 1952:206). 
"GEOGRAPHICAL POSITION HAS ENTITLED US"; COMPETITION BETWEEN EXTRACTIVE FIRMS OVER RAIL FREIGHT RATES TO THE CORE, 1929-I93I

Located on Michigan's Upper Peninsula, C\&H found itself located in the Western Trunk Line (WTL) territory, which had generally higher rates. The WTL was one of five rate territories (including Eastern/Official, Southern, Southwestern, and Mountain-Pacific), all of which had differing rates. In general, however, Eastern territory had significantly lower rates on manufactured goods than the other four territories, which charged lower rates for bulk goods (Hoogenboom and Hoogenboom 1976:138). Starting in the $19^{\text {th }}$ century, this basic structure was centered on Chicago, the traditional dividing point between the peripheral, generally agricultural west (as was the south) and the eastern industrial core, with typically lower rail rates on eastbound freight due to greater competition between railroads (and lake carriers) in the east than the more sparsely populated west, whose cargo also tended to be lower-value bulk commodities (Cronon 1991ะ83, 86-87). "The development of rate bureaus and of ICC-rate regulation in the twentieth century organized, institutionalized, and fixed these patterns into a rigid system" (Hoogenboom and Hoogenboom 1976:139).

Nonetheless, C\&H's Mechlin made repeated attempts to secure lower rail freight rates in the late ' 20 s and early ' 30 s, because the firm still depended on rail the five or six months each year the Great Lakes were frozen. Though an extractive firm in a peripheral region (the U.P. of Michigan, but also the WTL more generally), C\&H tended to side with industrial core interests on general freight rate policy. The ig2os had seen a general movement by industrial interests against the prevailing rail freight rate structure, prompted by the 1920 Federal Transportation Act (FTA) and the pro-agriculture 1925 Hoch-Smith Act. The I920 FTA was a regulatory adjunct to the U.S. rail system's reversion to private control after World War One, and made the Interstate Commerce Commission (ICC) "the authoritative voice of the federal government on the national transportation system," with more power than in its ineffectual pre-war years (Skowronek 1982:282; also Kennedy I991ः163; Hoogenboom and Hoogenboom 1976:I-83; Kolko I965:45-I26).

The FTA gave the ICC greater rate making power, allowing it to set both minimum and maximum rates. Further, protecting railway interests via allowing a "fair return" of $5^{3 / 4}$ percent on investment became as important as protecting rail consumers had been in preceding decades. Per Skowronek, "[ $t$ ]he ICC was charged with considering the nation's need for adequate transportation services" (1982:282-83). Whatever the increase in regulatory control, the railroads were now allowed to pool traffic, engage in mergers, "and create a consolidated system of regional railroad corporations" (Kennedy 1991:167). Five years later, when Hoch-Smith was passed to relieve the U.S.'s depressed agricultural sector of high rail freight rates, the railroads responded by raising rates on industrial customers. ${ }^{6}$ In opposition, C\&H's Mechlin asserted that Hoch-Smith would help farmers "at the expense of other industries which would have to pay increased rates to offset the lower classification given to agriculture" (Mechlin to MacNaughton, 26 June $1925, \mathrm{C} \& \mathrm{H} / 72 / 28 \mathrm{~b}$ ).

Though Mechlin saw $\mathrm{C} \& \mathrm{H}$ as aligned with industrial core interests on Hoch-Smith, the firm's own relative decline put it at odds with other firms in its own sector. While industrial complaints about freight rate structures led to an extended ICC investigation, the emergence of the integrated, large multinational copper firms prevented formation of a "united front" of copper producers on rail freight issues, as Mechlin complained in 1929; indeed, C\&H had spent the early and mid-rg2os trying to secure lower rail freight rates on its own. Copper's value was a further problem, which could hamper any chance at significant rate reductions, Mechlin informed his boss: "The most difficult argument we will have to meet is the value of our commodity as it effects [sic] the responsibility of the carrier in handling this traffic and unfortunately our part of the investigation comes at an inopportune time as far as the market price of copper is concerned" (Mechlin to MacNaughton, I3 March 1929, C\&H/73/54). Inconveniently enough for any rate reduction case, as Mechlin was well aware, I929 saw copper's highest average price since the war, 24 cents per pound, with an average price for the year at I8.I cents, highest in a decade (Herfindahl 1959:103; Gates 1951*205). However, the stock market crash the following year took the copper market down with it. An industry-wide downward trend, driven by the general business slowdown, along with expanded refinery capacity in Canada and Europe and expanded mining in Canada and Africa (Richter 1931:18; Pettengill 1935:436), helped drop Michigan copper's price from I8.I cents per pound in 1929, to 13.0 cents in 1930, and 8.I cents in I931, before bottoming at 5.6 cents in 1932 (Gates 1951:157-6I, 205).

Further, freight rates were still a bone of contention within the U.S.- per the Hoogenbooms' study, "[ $t$ ] here were thousands of specific rate cases in the I920s" (I976:100) — and C\&H management was still very concerned about western producers entering the firm's traditional midwest market, courtesy of dif-

6. However, new " $c$ c]ompetition from trucking and airlines closed off the traditional trade-off of agricultural service losses for high rates on more valuable freight" (Miranti I989: I I). 
ferentially low rail freight rates. Rate differentials were the western railroads' way of generating traffic, and of course also helped tie a burgeoning source of resources in an internal periphery to the U.S. industrial core. Resource characteristics were an additional consideration, for transport capital as well as extractive firms: again, coming into the I920s Michigan copper producers faced serious competition from the low grade porphyry copper producers in the southwestern U.S., particularly over freight rates, though the porphyry deposits had actually started coming online in 1904 (Schmitz 2000:87), producing large amounts of both ore and refined copper (see Chart I).

Phelps-Dodge, itself an initial victim of the I920s copper industry consolidations, still controlled large porphyry mines in Arizona and New Mexico, and proceeded to establish an electrolytic refinery in El Paso, Texas. The firm already owned its own local spur-line railroads, purchased to ensure service from the main transcontinental roads to its mines and smelters (Whitten 1983: 173). According to Phelps-Dodge's corporate biographer, El Paso's selection was "amply justified," the city having "[e]xcellent railroad facilities, reasonable proximity to the Pacific Coast, an abundant labor supply, and a central location with reference to the Phelps Dodge and other large copper mines and smelters of the Southwest" (Cleland 1952:222; also see Robbins 1994:32). C\&H's Burghardt agreed: he warned company chairman R.L. Agassiz that the El Paso refinery "will save [Phelps-Dodge] the cost of shipping blister [copper] to Atlantic seaboard and enable them to have refined copper on the ground for shipment anywhere in the United States without the expense of a back haul from the east" (Burghardt memo to Agassiz, 23 March 1928, enclosure with Burghardt to MacNaughton, 23 March 1928, C\&H/175/17).

Two years later, with the El Paso refinery completed, Mechlin informed C\&H's president that Phelps-Dodge was shipping an average of 55 tons of copper per rail car into Illinois, Indiana, Ohio, Michigan, western New York, western Pennsylvania, and St. Louis-in other words, C\&H's main geographical market. In comparison, $\mathrm{C} \& \mathrm{H}$ found it "impossible to maintain such an average as that of the Phelps-Dodge people [i.e. 55 tons per car] when we have so many orders to complete that call for only 20 or 25 tons." The real problem was not competition per sé, which already existed, but the effect on freight rates resulting from tonnage differences. For Michigan producers, part of the problem at this point was that their deposits were well along to being "played out," i.e. past the point of economical mining. Even by 1905, "the Lake Superior mines were working some of the lowest grade ores in the United States, from the deepest mine shafts in the world" (Schmitz 2000:92). For transport capital in particular, the tonnage from $\mathrm{C} \& \mathrm{H}$ was just not there anymore, despite the relatively high per unit value of Michigan's chemically-pure "native" copper. Mechlin
The Political Economy of Raw Materials Transport

warned that with over twice the tonnage per car, Phelps-Dodge's rail carriers would be earning much more than would C\&H's, "a point that the Interstate Commerce Commission examiners can not overlook in their comparison of car mile earnings as between the shipments of copper forwarded from El Paso and those made from the Michigan Copper District" (Mechlin to MacNaughton, 9 May 1930, C\&H/73/54).

In a letter to the Copper Country's primary rail carriers to "place ourselves on record...previous to the [ICC's] final hearing in the nonferrous metals case" (Mechlin to MacNaughton, 3I October 1930, C\&H/73/54), Mechlin argued that Michigan producers were hurt by competition resulting from freight rate reductions on copper shipped from the southwest (and Canada as well; see Mechlin to MacNaughton 23 and 26 May 1930, C\&H/73/54), to destinations in the area bordered by the Ohio and Mississippi Rivers on the south and west, and Pittsburgh and Buffalo on the east. According to Mechlin, these points were "destinations where the Michigan copper producing district in the past has held a not entirely unfavorable position with rates to which it's [sic] geographical position has entitled us"-in other words, these Midwestern points were C\&H's proverbial backyard. ${ }^{7}$ However, as part of the U.S. industrial core, they contained industrial firms requiring raw material inputs from wherever they could get them cheapest and in sufficient quantity, not just from Michigan.

Mechlin also asserted that C\&H was directly discriminated against "very substantially" on its own east-bound shipments, into "Trunk Line and New England territory," ${ }^{8}$ the initial U.S. core region (cf. Meinig 1978:II98; Meyer 1983). Again, the perceived rate discrimination was exacerbated by the Copper country's high mining and refining costs. Mechlin insisted that rates on refined copper from the Copper Country "be lowered to a basis comparable with those of our competitors.+. which will restore a proportionate geographical balance" to

7. Indeed, the following year Mechlin reported to MacNaughton that southwestern copper producers tried to make inroads into C\&H's literal backyard, when southwestern railroads had applied for through rates to ship Arizona copper to Dollar Bay in the upper Michigan Copper Country, where the Trenton, New Jersey-based firm Roebling \& Sons had a wire mill, which otherwise used C\&H's copper for raw material; see Mechlin to MacNaughton, 9 October I93 I, C\&H/74/ I Ia.

8. Trunk Line Territory included most of New York and Pennsylvania, except for their far western parts; most of West Virginia, the northern half of Virginia, New Jersey, Delaware, Maryland, and Washington, D.C. New England included its ostensible six states, as well as part of Quebec, and New York east of the Hudson (McPherson I9I2). 
the U.S. copper market. He warned that $\mathrm{C} \& \mathrm{H}$ was "prepared to support and defend [the proposed rates] if need be to the various carrier rate committees, or State and Federal Commissions," if the railroads in question did not take the matter to the regional freight committees (Mechlin to Duluth, South Shore \& Atlantic Railway and Mineral Range Railroad traffic manager S.R. Lewis and Copper Range Railroad general manager G.H. Wescott, 29 October 1930, enclosure with Mechlin to MacNaughton, 3I October 1930, C\&H/73/54). ${ }^{9}$

C\&H's rail carriers dutifully submitted the request to the pertinent regional freight associations, the Western Trunk Line (WTL) and the Central Freight Association (CFA). As it had throughout the 1920s, during C\&H's earlier efforts, the WTL's Standing Rate Committee issued an adverse report (see Mechlin to MacNaughton, 24 March 1931, C\&H/74/Ira). Its economic geography largely explains why: it covered the area between the Rockies and the Mississippi River, and also included Wisconsin and Michigan's U.P., a service area that was still mostly peripheral in terms of economic activity and general place in the world-economy; as a result, the average WTL railroad was financially worse off than the CFA roads. In other words, western railroads traveled longer distances between points, through emptier and less industrialized territory that generally did not yield "a fair return" on investment, as the ICC termed it (ICC 1935:613; also see McPherson 1912). Since copper producers were among the few major industrial enterprises in the western U.S., they were treated as favored customers by the western railroads, because their cargoes provided both tonnage and value, the ideal of transport capital, which can usually only expect one or the other from a given commodity. Covering the more heavily industrialized eastern portions of the U.S., the CFA was in turn more understanding with $\mathrm{C} \& \mathrm{H}$ 's application. Further, according to Mechlin, the CFA did not have much choice in the matter because other copper firms had also been granted lower rates, and it would be compelled to do so for $\mathrm{C} \& \mathrm{H}$ (Mechlin to MacNaughton, 6 April ı93ı, C\&H/74/ıia).

And even though the ICC established new "class rates" late in I93I, under which "every destination will be made to bear it's [sic] fair share of railroad freight burden in line with the length of haul and service performed"-as Mechlin approvingly informed MacNaughton (I6 November 1931, C\&H/74/ IIa) - the CFA then changed its policy toward $\mathrm{C} \& \mathrm{H}$, and began bringing gen-

9. Soon after, Mechlin admitted to MacNaughton that at least for some destinations, and at certain stages in the production process, $\mathrm{C} \& \mathrm{H}$ was not really being discriminated against (24 November $1930, \mathrm{C} \& \mathrm{H} / 73 / 54)$. erally negative decisions against the firm that very year (see Mechlin to MacNaughton, 6 October 193I). The CFA was instead granting more favorable rates to Montana copper producers, charging them less for copper rods than the Michigan producers were being charged (see Mechlin to Brunck, 7 December 1931, enclosure with Mechlin to MacNaughton, 7 December 193I, C\&H/74/IIa). Here again we see the imperative of transport capital in conjunction with the core-periphery dynamic within the U.S.--i.e. the railnet expanded to bring raw materials from further away on the continent to the northeastern and midwest core, which meant railroads had a great deal of expanded capacity to utilize in terms of tracks and rolling stock (and concurrently larger capital expenses to amortize), and therefore had an even greater prerogative to give lower rates to those producers whose commodities both had to be carried a greater distance (helping utilize track) and could provide greater volumes of those commodities (helping utilize rolling stock). By the I930s, the western U.S. copper producers' output far outstripped Michigan's, as well as being much further away from the industrial consumers of copper, so were more attractive customers on balance, and were granted lower rates. Raw materials producers in the "older" internal peripheries, closer to the core, were therefore at a disadvantage relative to producers further away, at least vis à vis rail freight rates. Of course, Michigan producers, led by $\mathrm{C} \& \mathrm{H}$, had the water option on the Great Lakes part of the year, but it was one partly foreclosed by the Great Depression.

“A MATTER OF COLD BUSINESS LOGIC": DECLINING PRODUCTION AND LOST TRANSPORT LINKS TO THE CORE, 1932-1939

As the I930s depression wore on, $\mathrm{C} \& \mathrm{H}$ was faced with low copper prices and low copper consumption-problems in part stemming from the productive overcapacity that resulted from new mines and increasing scrap recovery (Gates 1951:146-47; Richter 1931:18; Schmitz 1997:313). ${ }^{10}$ As a result, most Copper Country mines were shut down, except on the massive Calumet conglomer-

10. According to Cochran (I954:352), copper scrap recovery had started in the I920s, but Richter (1923:197) earlier pointed out that scrap copper had always been an important source of supply, not just because of copper's value, but also because much copper was consumed in recoverable forms. Also see Schmitz (I997:297), who points out that since copper is mostly non-corrodible and used for capital/durable goods, "very little of the accumulated stock of past production [is] completely lost." Freight rates on scrap copper briefly garnered the attention of C\&H's traffic manager during the depression; see Mechlin to MacNaughton, 23 November 1932, C\&H/74/ I Ia. 
ate lode, "too near the end of its life to warrant closing down and subsequent reopening" (Benedict 1952:199; also Gates 1951:16I-62). Again, decreased output was another potential bone of contention between an extractive firm and transport capital, for water as well as rail: $\mathrm{C} \& \mathrm{H}$ had drastically cut production-yet was still operating at a loss (Benedict 1952:199-205; Gates 1951:16I-63) - and generating enough cargo to attract the GLTC had become an even bigger concern for its traffic manager, who at one point wrote that "[w]e hope to have sufficient tonnage so that we will be able to have a boat come into our dock for all shipments" (Mechlin to MacNaughton, io June 1931, C\&H/74/IIa).

As a firm located in a now-declining extractive periphery (and with overall reduced demand, at least temporarily), $\mathrm{C} \& \mathrm{H}$ faced losing regularized transport service to its customers in the core regions of the US. As was essentially the case for the metals industry in general (EMJ 1926), the Copper Country's economy was supported by a surprisingly fragile dynamic between mining, smelting, and transport. If production was cut back due to high costs and depressed markets, then both rail and water carriers would have less incentive to include the district on their routes, leading to even higher production and transport costs, and increasingly restricted market access for minerals producers, particularly in a region that was still considered geographically marginal, as well as peripheral within the world-economy. C\&H's traffic manager articulated the potential loss of market access via restricted transport options to the Central Freight Association: "I can safely say that the closing down of these mines would mean the end of one railroad company's existence and the closing down of a 63 mile branch of another," because metal mining and smelting was the only significant freight producing industry in the Upper Peninsula_ per Mechlin, "there is no other industry at present than that of mining to warrant the continuance of railroad services." ${ }^{11}$ Of course, C\&H could always rely on water, should rail be discontinued or raise its rates too high, "although the service would not be as regular or convenient" (statement to Smelter Products Committee, Central Freight Association, 13 January 1932, enclosure with Mechlin to MacNaughton, I8 January 1932, $\mathrm{C} \& \mathrm{H} / 74 /$ IIa).

Not as regular or convenient, indeed: hence Mechlin's uncertainty vis à vis the GLTC, which evokes a sort of poignancy. As further evidence of C\&H's lesser position among the GLTC's customers, its copper was not shipped directly eastbound after being loaded at its Copper Country docks. Rather, its

${ }^{11 .}$ Indeed, by 1937, bankruptcy overtook the Duluth, South Shore \& Atlantic Railway, the main rail line on the Upper Peninsula (DuLong, n.d., http://habitant.org/ dssa/chrono.htm; also see Mechlin to MacNaughton, I3 April I933, C\&H/74/44). copper first went westbound to Duluth, a condition C\&H grudgingly acceded to (see Mechlin to MacNaughton, Io June 1931, C\&H/74/Ira; and see Map I). Still, the firm's minor dissatisfaction about its copper's roundabout trip grew significantly over the following two years (see Mechlin to MacNaughton, 9 June 1933, $\mathrm{C} \& \mathrm{H} / 74 / 44)$, as the need to minimize transport costs put $\mathrm{C} \& \mathrm{H}$ even more at the GLTC's mercy. Indeed, the GLTC had a virtual monopoly on water transport from Lake Superior to the lower lakes, one of only nine interlake, common-carrier package and passenger lines on the entire Great Lakes (U.S. Army Corps of Engineers 1937:408, 424) ${ }^{12}$

The Interstate Commerce Commission recognized the various difficulties that metals producers were under in its November 1934 decision on the nonferrous metals rate structure, based on an investigation prompted by manufacturers' protests over Congress' pro-agriculture (i.e. generally pro-periphery) I925 Hoch-Smith resolution. Though the ICC decided that nonferrous metal ore and concentrate freight rates were "less than [the] maximum reasonable," the Commission also acknowledged "that under present conditions the [nonferrous metals] industry cannot pay any increase in transportation charges" (ICC 1935:325). For upper Michigan copper producers in particular, the ICC also ruled that rail "rates to Midwest points give Michigan copper an advantage over copper from Montana and from the eastern refineries" primarily because water transport options helped suppress rail rates between the Copper Country and other midwestern points, but that while " $[t]$ he rates from refineries to the principal consuming points are not wholly consistent...there is no evidence of undue preference or undue prejudice" (ICC 1935:36I).

Despite the ostensible advantage of the lake option, C\&H's relations with the GLTC soured after the ICC's ruling, as the firm was continually plagued by GLTC delays and missed pickups during the 1935 navigation season. Mechlin lamented C\&H was "usually the victims of any disruption to the [GLTC's] regular shipping schedule," exacerbated by the needs of C\&H's new customer base, in turn reflective of an evolving industrial capitalism-by 1935, the firm's copper was "largely used in the production of automobiles," but auto makers were already practicing just-in-time production, "keep[ing] low stocks depending entirely on rapid transit service to keep the assembly lines in scheduled operation." Suppliers were therefore under tremendous pressure to get inputs to the manufacturers on time, as Mechlin was well aware: "If any delay occurs

12. The lack of carrying competition on the Great Lakes was largely due to legal restrictions preventing railroads from also owning lake carriers (see above), a fact later bemoaned by Mechlin (to MacNaughton, 29 November 1933, C\&H/74/44). 
in getting our metal to the manufacturing units and thence to the motor companies, it is obvious that we are sure to suffer permanent loss of business." If the GLTC could not improve its service, Mechlin again threatened to move $\mathrm{C} \& \mathrm{H}$ to all-rail shipments during the navigation season (Mechlin to Noble, 7 November $1935, \mathrm{C} \& \mathrm{H} / 74 / 79$ ).

In trying to assuage Mechlin, the GLTC's Noble expressed appreciation for C\&H's recent business (in tonnage terms no less), though he admitted that late in the navigation season his firm's imperative was, per usual for transport capital, "just a question of getting [the ships] around as fast as we can, and mov[ing] all the tonnage possible on each ship." He also pinned C\&H's specific complaint on the auto companies' just-in-time production methods, "which probably resulted in the receivers not always being able to anticipate their needs far enough in advance," a matter he was willing to discuss further and hopefully make arrangements to obviate any future occurrence (Noble to Mechlin, I4 November 1935, C\&H/74/79). Noble's solicitousness was perhaps motivated by the new competitor to the GLTC's steamboats, motor-driven ships that allowed direct all-water transport to the east coast and its "copper fabricating centers," a potential option that concerned the eastern railroads that took C\&H's copper from Buffalo to the east coast. In part, this was also because an east coast copper fabricating firm (Stamford Rolling Mills, in Connecticut) was attempting to secure lower freight rates for C\&H's copper "in the belief that they would profit in such an adjustment," though $\mathrm{C} \& \mathrm{H}$ management chose not to clarify matters regarding who was pushing for the lower rate (see Mechlin to MacNaughton, I April 1936; Mechlin to E.W. Brunck, assistant freight traffic manager, Michigan Central Railroad Company, I8 September 1936, enclosure with Mechlin to MacNaughton, I8 September 1936, C\&H/74/79).

When it looked like the eastern railroads would not agree to a rate reduction, "as any change in [C\&H's] rates would disturb the whole nation-wide copper rate schedule," Mechlin suggested to one of his railroad counterparts that unless east-bound copper freight rates were reduced for $\mathrm{C} \& \mathrm{H}$, he foresaw the possibility of copper fabricating capital flight out of the eastern U.S. and "into C.F.A. or W.T.L. territory where the greater part of Lake copper now reaches its final manufacturing stage," with a resultant loss of tonnage for the eastern railroads (Mechlin to J.D. Switzer, division freight agent, New York Central Lines, II June 1936, quoted in letter to MacNaughton, 23 June 1936, $\mathrm{C} \& \mathrm{H} / 74 / 79)$. However, it was the upper midwest rail carriers of the CFA that "refused concurrence" on a lower rate for C\&H copper shapes to Connecticut, much to C\&H management's "surprise and disgust," since the CFA "had no direct interest" in the rates. As Mechlin saw it, it was a move "taken as a blow" against the GLTC (Mechlin to Brunck, I8 September 1936, enclosure with Mechlin to MacNaughton, I8 September 1936, C\&H/74/79). The charge makes sense when considering that other modes of transport (e.g. trucking, airplanes, motor-driven ships) were cutting into railroads' freight business, which was declining anyway due to the depression (Miranti 1989:12). A consequence of larger trends in the development of the means of transport, $\mathrm{C} \& \mathrm{H}$ got caught between two fractions of transport capital in this instance, further exacerbating their market/core access difficulties.

Depressed business conditions also brought matters to a head with the lake carrier GLTC. Deprived of the lower eastbound rate in 1936, C\&H was still considering a motorship contract in 1939 for cheaper all-water eastbound copper shipments. If $\mathrm{C} \& \mathrm{H}$ did so, the GLTC indicated it would in turn have to discontinue its service to Houghton, Lake Linden, and other Copper Country ports (see Map 2), because about three-quarters of the tonnage it transported from the upper Michigan Copper Country came from C\&H. Per GLTC management therefore, raising the possibility of discontinuing service "was not offered in the nature of a threat but as a matter of cold business logic." $\mathrm{C} \& \mathrm{H}$ management was steadfast, though Mechlin recognized the GLTC and eastern railroads' prior efforts to lower the rates charged $\mathrm{C} \& \mathrm{H}$, which were obstructed by the ICC and rejected by the midwestern railroads of the CFA (see above; Mechlin to MacNaughton, 16 March and I7 April 1939; MacNaughton to Mechlin, 5 April 1939, C\&H/75/78). Though a peripherally-located supplier of raw materials to the U.S. core regions, other peripherally-located suppliers (chiefly in the western U.S.) could provide transport capital with greater tonnage over longer distances, thereby enabling greater capacity utilization over the increasing distances from periphery to core. Overall, by the late 1930s C\&H was still paying more to move its copper by rail into the "Official"/eastern rate classification territory than those producers shipping from the Western Classification territory, particularly when $\mathrm{C} \& \mathrm{H}$ was shipping less than a full carload, which the firm did on "numerous" occasions, at least in part by way of an attempt "to broaden the market" for their copper (Mechlin to MacNaughton, 20 December 1938, C\&H/75/42).

The GLTC soon acted on their "cold business logic" and discontinued most direct boat service to C\&H's Copper Country docks, effective 3I July 1939 (though it maintained service to the main community of Houghton with "a promise of calling at Hubbell for a minimum of too tons"; Mechlin to MacNaughton, 5 July 1939, C\&H/75/78). Such were the economics of Great Lakes transport, a genuine constraint for a firm that mined and processed a nonferrous base metal in a remote region. Unlike precious metals, for which "transport costs are a significant, but rarely dominant, consideration; with base metals low transfer charges are a prerequisite of successful operation" (Warren 
1973:57) — and certainly make a difference for a firm under larger structural pressures as well, i.e. higher cost mineral deposits relative to its competitors, a changing industrial structure, and a depressed world-economy.

To rephrase, for $\mathrm{C} \& \mathrm{H}$, copper's value allowed rail transport, especially when water was not available. In contrast, the firm was not able to do the same with coal, a commodity with a much lower value: it had to ship all its coal during the limited water navigation season (Leitner 1998:216-307). However, even when water transport was available, copper fell uncomfortably between bulk cargoes, which were dominant on the Great Lakes, and high-value precious metals. Copper, in particular the chemically-pure version mined in upper Michigan, was not really a bulk good, thus did not utilize by itself the amount of cargo space that grain, iron ore, or coal all did—but neither was it so valuable that $\mathrm{C} \& \mathrm{H}$ management could afford not to be concerned about freight rates. The ability to move increasingly larger amounts of decreasingly valuable bulk raw materials was key to the U.S.'s ascent up the world-economic hierarchy, from semiperiphery to core and eventually hegemon, as indeed it has been for ascending hegemonic powers throughout the history of the capitalist worldeconomy (Bunker and Ciccantell 1999; Ciccantell and Bunker 2002:63-70). The irony for $\mathrm{C} \& \mathrm{H}$ was that it indeed was a core firm, in terms of where its initial capital came from, where its directors were based, and the scale of capital investment involved in its operations (Gates 195I), if perhaps not in terms of value-added (since it lacked serious manufacturing capacity until after World War Two, and then it was located outside of the Copper Country). Its primary location however, was certainly not core: a peninsula in the middle of Lake Superior, a relatively "hard" geographic enclave, in which resource extractive capital was plunked down in a "relatively untouched wilderness...using modern technologies and demanding large-scale investments" (Massa 1999:129). The irony for the region was that after nearly a century of Euroamerican settlement and intensive mining activity, the upper Michigan Copper Country was once again a difficult place to reach by boat, as it had been in the I840s-50s (Lankton 1997:23-36, 46-47; Clarke I853), certainly undercutting the old linkage theory supposition about resource transport as "the most important...and powerful" backward linkage to further development (Watkins i963:I45).

\section{THE DIALECTIC OF EXTRACTIVE CAPITAL, INDUSTRIAL CAPITAL,} TRANSPORT CAPITAL AND NATURAL RESOURCES IN U.S+ CORE ASCENT: THE CONTEXT OF C\&H'S BIND

Of course, "development," such as it is in peripheral extractive regions, is not always such a permanent thing, even within otherwise core countries (which can at least better meliorate the negative effects; Hanna 1995). Throughout the $19^{\text {th }}$ century and into the $20^{\text {th }}$, U.S. mining regions like upper Michigan's Copper Country typically ${ }^{13}$ declined as they were "played out" (i.e. extraction became a higher-cost proposition relative to other sources of the raw material), while the means of transport were extended further out to bring raw materials to the northeastern (and increasingly midwestern) core region. This "low-cost transport network was a central part of the United States' rapid industrialization, the key to U.S. ascendance in the world-economy" (Bunker and Ciccantell 1999:I16). Of course, this low-cost network benefiting core manufacturing capital entailed increasing investments by transport capital, which had greater and greater capacities that had to be utilized, i.e. the fixed costs that never went away, especially for railroads (Cronon 1991:83-89). The basic dynamic at work during this process was that geographic expansion of the U.S. across North America both drove and was driven by the need to bring resources to the Northeast-Midwest core region and its burgeoning industries from further away while keeping transport rates low, hence an expansion of transport infrastructure-a continuing cycle over the course of world-economic history (Bunker 2003:252). More generally, per Bunker (2003:22I), "Industrial economies expand materially while agglomerating spatially," i.e. there is more incentive for capital to invest in areas where capital is already deeply invested (Scott 1995; Meyer 1983); but natural resource inputs then have to be acquired from further and further away.

As we saw above, transport capital plays a major mediating role in getting peripheral extractive resources to core regions, driven by its need to keep said expanded transport infrastructure and capacity utilized to as full extent as possible-ergo, lower rates offered to extractive firms that could supply more tonnage, with transport economics in turn derivative of U.S. industrial and geographical expansion (and the nation-state's concurrent ascent up the worldsystem hierarchy), as much as it helped drive those larger processes. A given firm like $\mathrm{C} \& \mathrm{H}$ was therefore up against the railroads' and lake carriers' basic imperative to ensure as full utilization of cargo space as possible and to maximize the value of those cargoes-and why its attempts to secure more favorable freight rates in the I920s-30s involved continuous efforts and (per Mechlin) constant alertness to rate changes. Indeed, the imperatives of transport capital are a component in the struggles of other peripheral interests (particularly farmers) in the U.S. in the late $19^{\text {th }}$-early $20^{\text {th }}$ century to secure more favorable

13. Though not universally; see Freudenburg and Frickel (1994), Frickel and Freudenburg (I996). 
rail freight rates (see Farmer 1926; Higgs 1970). These transport capital imperatives at times also worked in peripheral interests' favor, when it was in transport capital's interest to charge producers in peripheral regions lower rates, in order to compete with alternate transport modes such as happened on both the Great Lakes as well as central California (e.g. Magliari 1989); or more likely to generate traffic in agricultural and extractive regions (e.g. Rothstein 1975:275-76; Berk 1994:129-40), such as the favorable rates granted the far western copper producers, which like $\mathrm{C} \& \mathrm{H}$ were core firms operating industrial enclaves in otherwise peripheral regions, but could supply large, valuable tonnages to western railroads (Robbins 1994:32-33, 38, 89, 93, 132-33; more generally, Schmitz 1986, 2000).

At the same time, $\mathrm{C} \& \mathrm{H}$ management also had to deal with copper's changing industrial structure, as the firm's competitors beyond the Copper Country diversified, vertically integrated, and even expanded overseas. Following from Schmitz (1986, 1997, 2000), copper's industrial restructuring was very much a consequence of its physical characteristics, an observation in line with the work of Bunker and his colleagues, who assert that the physical characteristics of natural resources play key roles in structuring the political and economic strategies of ascent within the world-system hierarchy (Bunker and O'Hearn 1993; Barham et al 1994; Bunker and Ciccantell 1995a, 1995b, 1999; Ciccantell and Bunker 2002; Bunker 2003). Dominated at the time by U.S. firms, the copper industry's changing structure was driven by the changes in the physical characteristics of the ores being extracted. Surficially extensive, low grade porphyry deposits became the most important source of copper ore, and the high capital requirements for mining such deposits prompted the creation of bigger firms (Schmitz 1986, 2000; Whitten 1983:175-76).

This move to more extensive, lower grade ores than C\&H's rare, chemicallypure variety was itself prompted by the U.S. economy's increasing consumption of raw materials in its ascent up the world-system hierarchy, helped of course by the fact that it initially had easy access to these resources in its own internal peripheries (Wright 1990). From the I89os on, and certainly through the I920s and '3os, the U.S. was far and away the world leader in copper mining, smelting, and refining (Schmitz 1997:303, 31I). Within the U.S., the copper industry's I920s restructuring was a component of U.S. core ascent, with its domicile firms securing access to a key raw material as older deposits of that material neared effective depletion-a sectoral-level manifestation of the "proto-autarkic" policies pursued by the U.S. (and other core states) in the I930s, during the interregnum between British and U.S. hegemonies, as the liberal world trading regime collapsed ( $\mathrm{Su} 2001: 44-49)$, as well as contributing to the resource transport dynamic between transformative, extractive, and transport capital.
Though beneficial for purposes of continued U.S. ascent, as well as benefiting the copper sector's leading firms, the industry's restructuring (and accompanying transport cost alteration) at the level of a given firm could well be less sanguine: for its part, $\mathrm{C} \& \mathrm{H}$ was placed at a disadvantage in the marketplace by suddenly losing its key customers, and then being forced to go farther afield for new ones (at higher rates), at the same time as its own copper deposits were depleting and becoming very expensive to extract.

Again, the political economy of transport capital (and more particularly freight rates) during this episode of U.S. world-system ascent were tied in to the need to transport natural resources over increasing distances to transformative firms in the core regions, which necessitated increasing transport infrastructure and further pushed railroad and lake carriers' imperatives for either high volume "bulk" cargoes or very high value cargoes-which in turn made matters difficult for shippers of products that were not quite one or the other. Copper was one of those in-between products, with a value high enough to keep rail freight rates higher than $\mathrm{C} \& \mathrm{H}$ would have preferred, but not high enough to offset the lack of bulk that made it a less desirable cargo for lake carriers. While this made for great contention between $\mathrm{C} \& \mathrm{H}$ and its freight carriers, C\&H's struggle to redress perceived rate imbalances was therefore also part of larger internal core-periphery struggles as U.S. industrialization deepened during the early $20^{\text {th }}$ century. The 1925 Hoch-Smith law was a prime example of agricultural interests' struggle against what they saw as growing imbalances in favor of heavy industry, particularly over rail charges, which in turn provoked the industrial sector's grievance. Redress was ultimately a political matter, albeit largely driven by the railroads' narrow economic imperatives. As one historian of U.S. populism put it: "The truth seems to be that there was no such thing as a scientific [freight] rate. Neither railroad managers, nor farmers, nor railroad commissions had any scientific principle to guide them in the matter of ratemaking. To point out manifest injustices in certain specific rates was easy. To fix a just rate was difficult" (Farmer 1926:390).

The larger point then is that the political economy of domestic U.S. raw materials transport at this time was a manifestation of the larger core-periphery division within the U.S., which has comprised the U.S, political economy's underlying structure since the mid-19 ${ }^{\text {th }}$ century, if not earlier (Rubinson 1978; Chase-Dunn 1980; Bensel 1984; Agnew 1987; Dunaway 1996a). While the U.S. nation-state on balance benefited from its internal store of natural resources and the transport systems that carried them to core areas (Wright 1990; Bunker and Ciccantell 1999), the arrangement was less beneficial to extractive regions cast in the role of internal peripheries, often to their long-term detriment. Formally speaking, copper freight rates in the U.S. were designed to facilitate 
Map 3 - U.S. State Geography of Copper Smelting \& Production, ca. 1935

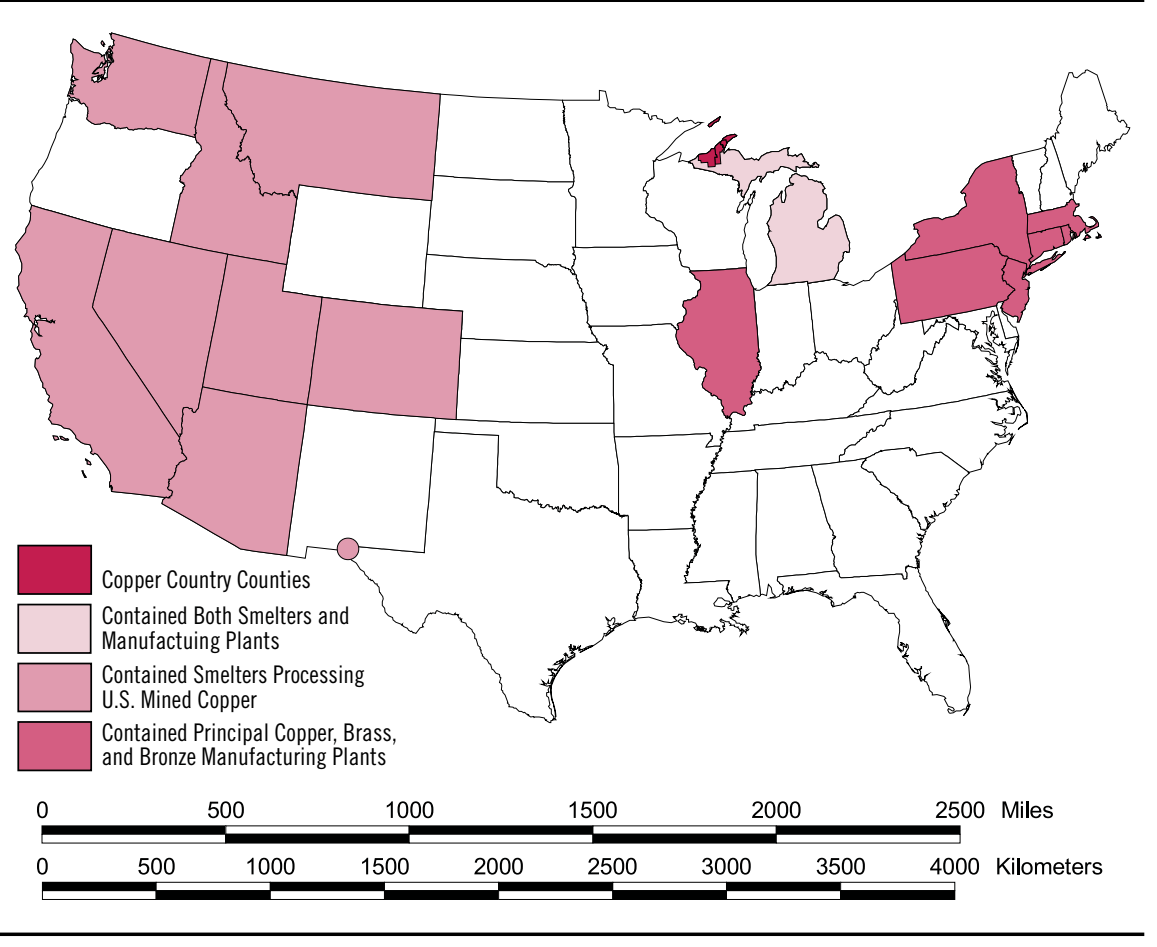

Source: I.C.C. $(1935 \div 324-25)$

the movement of raw metal from periphery to core, as were most raw material freight rates. In its decision on the nonferrous metals rate structure, the I.C.C. $(1935 \div 324-25)$ pointed out that except for Michigan, the smelters producing raw copper from U.S. ores were "all located west of the $105^{\circ}$ meridian in Montana, Idaho, Washington, Utah, Colorado, Nevada, California, ....Arizona, and at El Paso, Tex.," while 95 percent of this copper was then consumed east of the Mississippi River, where the "principal [copper, brass, and bronze] manufacturing plants" were located in the states of Connecticut, Massachusetts, Rhode Island, New York, New Jersey, Pennsylvania, Michigan, and Illinois (see Map 3).

For C\&H in particular, the commodity frontier (cf. Moore 2000) for copper in North America had quite literally passed it by, with the major producers now well to the west; it was left as a high-cost producer not far from the U.S.'s main core regions (indeed within a state that also had copper consuming firms), but too close and not producing enough to get the kind of freight rate price breaks offered its western competitors - and the largest of which were integrating via acquisition of those in-state Michigan copper consumers as well. For the copper industry in general, its I930s geographical structure within the U.S. mirrored the contemporaneous global core-periphery structure of copper producers and consumers, with several countries as major mineral producers (Chile, Canada, the African copper belt) and several as major consumers (led by Britain, Germany and France), while the U.S. was both-"a largely self-contained copper market" (Schmitz 1997:314), whose core regions could draw on domestic supplies in internal extractive peripheries.

Transport capital, particularly rail, was therefore a key agent of incorporation, hence peripheralization, tying resource-rich regions to the core; and transport policymaking and administrative decisions about freight rates on balance favored the U.S. industrial core, at least up through the I940s (Kennedy I99I; Berk 1994; Hoogenboom and Hoogenboom 1976:I4I-42) —or as a leading Roosevelt administration official put it, "the 'freight rate structure was planned to clinch the industrial supremacy of the North and East'" (Harry Hopkins, 1938, in Hoogenboom and Hoogenboom 1976:140). The 1925 Hoch-Smith Act was arguably an exception, in that peripheral agricultural interests were favored. Though C\&H cast itself with the industrial interests against Hoch-Smith, it might have been better off under a rail freight regime that was more favorable to peripheral interests - the railroads' structural imperative for maximizing throughput led them to favor core customers that offered either larger or more valuable cargoes, often at the expense of peripheral and/or smaller customers, like farmers and "small town manufacturers" (Kennedy 1991ः159-60). C\&H's main lake carrier, the GLTC, operated by similar criteria, and placed greater priority on the large grain dealers at Duluth who could supply more overall business. Though C\&H was certainly not a small firm, it was considerably smaller than its chief competitors based in the western U.S., large copper producers who were valued customers for western railroads. Its relatively small size and its increasing operating costs meant that $\mathrm{C} \& \mathrm{H}$ was left behind by the working out of the contradictions between scale and space in the burgeoning U.S. industrial economy, i.e. the ever-greater need for both raw materials and the economies of scale required to transport those raw materials cheaply-which in turn "drove further scale increases in consumption of raw materials, reiterating the contradiction anew" (Bunker 2003:252).

Yet while opposed to a pro-agriculture measure like Hoch-Smith, and funded by capital from the core region of the northeastern U.S. (Gates 195I), C\&H's struggle for lower freight rates in the 1920 s and ' 30 s bears greater resemblance to that of a peripheral actor. More accurately, we could speak of C\&H as a core firm that found itself trapped in a peripheral region, ironically facing some of the same exploitative practices vis à vis freight rates on its products 
that characterize core-periphery transport transactions, particularly regarding rising core economies that manage to keep their overall raw material costs low at the expense of their raw material supply peripheries (Ciccantell 200I*62; Ciccantell and Bunker $1998 \mathrm{~b}: 8-9)$. There is further evidence that C\&H's corporate behavior in this period was more indicative of a peripheral actor: as mentioned above, the senior managers' decision not to forward integrate into manufacturing, as its larger competitors were doing, and become a firm engaged in a decidedly core process. Instead, the firm remained largely engaged in extraction and primary processing until the 1940s, with the misfortune of having its production costs reaching untenably high levels at the same time the 1930s depression hit.

Of course, per Chase-Dunn (1989:207-08), firms (and states) are not core or peripheral in their entirety, but rather located along a continuum, with certain firms engaged in activities at different levels of the continuum; it is regions that should be considered core or peripheral. By way of extension, peripheral regions may place certain constraints on the firms located there, even if those firms otherwise manifest ostensibly core characteristics. This seems particularly true of extractive enterprises; as Bunker and his colleagues have found, extractive firms may become constrained by the physical geographies of the regions they operate in (Barham et al 1994; Bunker 1992, 2003; Bunker and Ciccantell 1995a).

While examining the firm is another way to explore how the world-economy plays out at the (near) micro level, the limit to any conclusion of regional constraint on a firm is of course that large multinational (or in this case multiregional) firms headquartered in core regions still have a greater range of options than do small producers. For their part, large extractive firms have an inclination to "cut-and-run"; and over the course of the I930s, depressed markets, increasing production costs and increasing transport costs prompted $\mathrm{C} \& \mathrm{H}$ to begin searching for alternative investment fields, albeit outside the region it had been located in (Benedict 1952:206, 235-43). Indeed, at the same time as it struggled for lower freight rates, the firm had been liquidating its assets, making \$48 million of shareholder payouts during 1919-29 (Gates 1951:156). Though the firm continued its Copper Country operations until 1969, the Depression era marked the beginning of the end for C\&H's involvement in the region, and the region's economic identity as a mining center, as it went from being a resourceextractive internal periphery to one officially-classified as "government dependent" (USDA-ERS 1989).

\section{REFERENCES}

Agnew, John A. 1987. The United States in the World-Economy: A Regional Geography. Cambridge: Cambridge University Press.

Arrighi, Giovanni. 1999. "The Global Market." Journal of World-Systems Research $\mathrm{v}(2): 2 \mathrm{I} 7-25 \mathrm{I}$. http //jwsr.ucr.edu

Barbour, Percy E. 1935. "Copper." The Mineral Industry 43: II6-I5I.

Barbour, Percy E. 194I. "Copper." The Mineral Industry 49: I29-180.

Barham, Bradford, Stephen G. Bunker, and Denis O’Hearn. I994. "Raw Materials Industries in Resource-Rich Regions," pp. 3-38 in States, Firms, and Raw Materials: The World Economy and Ecology of Aluminum, Bradford Barham, Stephen G. Bunker and Denis O'Hearn, eds. Madison: University of Wisconsin Press.

Barry, James P. 1973. Ships of the Great Lakes: 300 Years of Navigation. Berkeley, CA: Howell-North Books.

Beaman, Jay, and Joseph Hraba. I991. "Fraser, Iowa: An Historical Case of Coal Company Control and Decline on the Periphery." Wisconsin Sociologist 28(I): $38-48$.

Benedict, C. Harry. 1952. Red Metal: The Calumet and Hecla Story. Ann Arbor: University of Michigan Press.

Bensel, Richard Franklin. 1984. Sectionalism and American Political Development: 1880-1980. Madison: University of Wisconsin Press.

Berk, Gerald. 1994. Alternative Tracks: The Constitution of American Industrial Order, 1865-1917. Baltimore: Johns Hopkins University Press.

Billings, Dwight B. and Kathleen M. Blee. 2000. The Road to Poverty: The Making of Wealth and Hardship in Appalachia. Cambridge: Cambridge University Press.

Boyd, William, W. Scott Prudham, and Rachel A. Schurman. 200I. "Industrial Dynamics and the Problem of Nature." Society and Natural Resources I4(7): 555-570.

Bunker, Stephen G. 1992. "Natural Resource Extraction and Power Differentials in a Global Economy," pp. 6I-84 in Understanding Economic Process, Sutti Ortiz and Susan Lees, eds. Lanham, MD: University Press of America.

Bunker, Stephen G. 1994. "The Political Economy of Raw Materials Extraction and Trade," pr. 437-450 in Industrial Ecology and Global Change, R.H. Socolow, C. Andrews, V. Berkhart and V. Thomas, eds. Cambridge: Cambridge University Press.

Bunker, Stephen G. I996. "Transport and Hegemony." Paper presented to the 2Ist annual meeting of the Political Economy of the World-System section of the American Sociological Association, Manhattan, KS, April 20.

Bunker, Stephen G. 2003. "Matter, Space, Energy, and Political Economy: The Amazon in the World-System." Journal of World-Systems Research Ix (2): 219258. http://jwsr.ucr.edu 
Bunker, Stephen G., and Paul S. Ciccantell. 1995a. "Restructuring Markets,

Reorganizing Nature: An Examination of Japanese Strategies for Access to Raw Materials." Journal of World-Systems Research I (3). http://jwsr.ucr.edu

Bunker, Stephen G., and Paul S. Ciccantell. 1995b. "Restructuring Space, Time, and Competitive Advantage in the Capitalist World-Economy: Japan and Raw Materials Transport after World War II," Pp. I09-I29 in A New World Order?: Global Transformations in the Late Twentieth Century, David A. Smith and József Böröcz, eds. Westport, CT: Greenwood Press.

Bunker, Stephen G., and Paul S. Ciccantell. I999. "Economic Ascent and the Global Environment: World-Systems Theory and the New Historical Materialism," PP. 107-I22 in Ecology and the World-System, Walter L. Goldfrank, David Goodman, and Andrew Szasz, eds. Westport, CT: Greenwood Press.

Bunker, Stephen, and Denis O'Hearn. I993. "Strategies of Economic Ascendants for Access to Raw Materials: A Comparison of the U.S. and Japan," Pp. 83-IO2 in Pacific Asia and the Future of the World-System, Ravi Arvid Palat, ed. Westport, CT: Greenwood Press.

$\mathrm{C} \& \mathrm{H}$. The Calumet and Hecla Mining Companies Collection. Michigan Technological University Archives and Copper Country Historical Collections, Houghton, MI.

C\&H I979. Records of the Calumet and Hecla Consolidated Copper Co., acquired from Universal Oil Products Inc,, I3 December I979 donation to Michigan Technological University Archives and Copper Country Historical Collections, Houghton, MI.

C\&H 1985. Records of the Calumet and Hecla Consolidated Copper Co., acquired from Universal Oil Products Inc., I985 donation to Michigan Technological University Archives and Copper Country Historical Collections, Houghton, MI.

Chase-Dunn, Christopher. 1980. "The Development of Core Capitalism in the Antebellum United States: Tariff Politics and Class Struggle in an Upwardly Mobile Semiperiphery," PP. I89-230 in Studies of the Modern World-System, Albert Bergesen, ed. New York: Academic Press.

Chase-Dunn, Christopher. 1989. Global Formation: Structures of the World-Economy. Cambridge, MA: Basil Blackwell Inc.

Ciccantell, Paul S. I994. "Raw Materials, States and Firms in the Capitalist World Economy: Aluminum and Hydroelectricity in Brazil and Venezuela." Ph.D. dissertation, University of Wisconsin.

Ciccantell, Paul S. 200I. "NAFTA and the Reconstruction of U.S. Hegemony: The Raw Materials Foundations of Economic Competitiveness." Canadian Journal of Sociology 26(I): 57-87.

Ciccantell, Paul S., and Stephen G. Bunker, eds. I998a. Space and Transport in the World-System. Westport, CT: Greenwood Press.

Ciccantell, Paul S., and Stephen G. Bunker. 1998b. "Introduction: Space, Transport, and World-Systems Theory," PP. I-I5 in Space and Transport in the World-System, Paul S. Ciccantell and Stephen G. Bunker, eds. Westport, CT: Greenwood Press.
The Political Economy of Raw Materials Transport

Ciccantell, Paul S., and Stephen G. Bunker. 2002. "International Inequality in the Age of Globalization: Japanese Economic Ascent and the Restructuring of the Capitalist World-Economy." Journal of World-Systems Research VIII (I): 62-98. http://jwsr.ucr.edu

Clarke, Robert E. I853. "Notes From the Copper Region." Harper's New Monthly Magazine 6: 433-448, 577-588,

Cleland, Robert Glass. 1952. A History of Phelps Dodge, 1834-1950. New York: A.A. Knopf.

Cochran, Ray. 1954. "Secondary Copper and Copper Alloys," PP. 352-359 in Copper: The Science and Technology of the Metal, Its Alloys and Compounds, Allison Butts, ed. New York: Reinhold Publishing Corporation.

Cronon, William. I99I. Nature's Metropolis: Chicago and the Great West. New York: W.W. Norton \& Co.

De Oliver, Miguel. 1995. "Structural Consolidation: The Colorado Delta Region, I900-Io." Review: Fernand Braudel Center xviri (4): 565-588.

Dowd, Douglas F. 1977. The Twisted Dream: Capitalist Development in the United States since $1776+2^{\text {nd }}$ ed. Cambridge, MA: Winthrop Publishers, Inc.

DuLong, John P. n.d. Duluth, South Shore, and Atlantic Railway homepage. http://habitant.org/dssa

Dunaway, Wilma A. I996a. The First American Frontier: Transition to Capitalism in Southern Appalachia, 1700-1860. Chapel Hill: University of North Carolina Press.

Dunaway, Wilma A. I996b. "The Incorporation of Mountain Ecosystems into the Capitalist World-System." Review: Fernand Braudel Center xIx (4): 355-38I.

EMJ. I915. "Lake and Rail Lines." Engineering and Mining Journal 99(23)ः 1003.

EMJ. 1926. "Railroad Rates and Ore Reserves." Engineering and Mining Journal I $22(3): 82-83$.

EMJ. I927a. "Delivery Charges on Refined Copper." Engineering and Mining Journal I23(7): 274-275.

EMJ. 1927b. "Last Boat Shipments of Year Leave Michigan Smelters." Engineering and Mining Journal I24(25): 985.

Farmer, Hallie. 1926. "The Railroads and Frontier Populism." Mississippi Valley Historical Review I3 (3): 387-397.

Fay, Albert Hill, ed. I9II. "Copper." The Mineral Industry I9: I49-227.

Francaviglia, Richard V. I99I. Hard Places: Reading the Landscape of America's Historic Mining Districts. Iowa City: University of Iowa Press.

Freudenburg, William R., and Scott Frickel. 1994. "Digging Deeper: MiningDependent Regions in Historical Perspective." Rural Sociology 59(2): 266-288.

Frickel, Scott, and William R. Freudenburg. 1996. "Mining the Pastः Historical Context and the Changing Implications of Natural Resource Extraction." Social Problems 43(4): 444-466.

Gann, L.H. I955. "The Northern Rhodesian Copper Industry and the World of Copper: 1923-1952." Rhodes-Livingstone Journal I8: I-I8. 
Gates, William B., Jr. I95I. Michigan Copper and Boston Dollars: An Economic History of the Michigan Copper Mining Industry. Cambridge, MA: Harvard University Press.

Hanna, Stephen P. I995. "Finding a Place in the World-Economy: Core-Periphery Relations, the Nation-State and the Underdevelopment of Garrett County, Maryland." Political Geography I4(5): 45I-472.

Herfindahl, Orris C. 1959. Copper Costs and Prices: 1870-1957. Baltimore, MD: The Johns Hopkins Press.

Higgs, Robert. 1970. "Railroad Rates and the Populist Uprising." Agricultural History $44(3): 29 I-297$.

Hildebrand, George H., and Garth L. Mangum. I992. Capital and Labor in American Copper, 1845-1990: Linkages Between Product and Labor Markets. Cambridge, MA: Harvard University Press.

Hoogenboom, Ari, and Olive Hoogenboom. 1976. A History of the ICC: From Panacea to Palliative. New York: W.W. Norton \& Co.

Hugill, Peter J. 1993. World Trade Since 1431: Geography, Technology, and Capitalism. Baltimore, MD: Johns Hopkins University Press.

ICC. I9I3a. Decisions of the Interstate Commerce Commission of the United States. Vol. 25. Washington: United States Government Printing Office.

ICC. I9I3b. Decisions of the Interstate Commerce Commission of the United States. Vol. 26. Washington: United States Government Printing Office.

ICC. I935. Decisions of the Interstate Commerce Commission of the United States. Vol. 204. Washington: United States Government Printing Office.

Ingalls, W.R. I9I2. "How the Metals Are Sold-Copper." Engineering and Mining Journal 93 (I 8): 887-890, (I9): 939-942.

Johnson, Homar L. I929. “Copper." The Mineral Industry 37: I23-172.

Kennedy, Robert Dawson, Jr. I99I. "The Statist Evolution of Rail Governance in the United States, I830-I986," PP. I38-I8I in Governance of the American Economy, John L. Campbell, J. Rogers Hollingsworth and Leon N. Lindberg, eds. Cambridge: Cambridge University Press.

Kolko, Gabriel. 1965. Railroads and Regulation, 1877-1916. Princeton, NJ: Princeton University Press.

Lankton, Larry. 1997. Beyond the Boundaries: Life and Landscape at the Lake Superior Copper Mines, 1840-1875. New York: Oxford University Press.

Leitner, Jonathan. I998. "Upper Michigan's Copper Country and the Political Ecology of Copper, I840s-I930s." Ph.D. dissertation, University of Wisconsin.

Leitner, Jonathan. 2000. "The I869 Copper Tariff: The Politics and Geography of Postbellum U.S. Development in World-System Perspective." Sociological Perspectives 43(4): 473-497.

Leitner, Jonathan. 200I. "Red Metal in the Age of Capital: The Political Ecology of Copper in the Nineteenth-Century World-Economy." Review: Fernand Braudel Center $\operatorname{xxiv}(3): 373-437$.
The Political Economy of Raw Materials Transport

Leitner, Jonathan. 2003. "North American Timber Economy: Log Transport, Regional Capitalist Conflict, and Corporate Formation in Wisconsin's Chippewa Basin, I860-1900." Review: Fernand Braudel Center xxvi(2): 173-219.

McPherson, Logan G. I9I2. Railroad Freight Rates in Relation to the Industry and Commerce of the United States. New York: Henry Holt and Company.

Magliari, Michael. I989. "Populism, Steamboats, and the Octopus: Transportation Rates and Monopoly in California's Wheat Regions, I890-I896." Pacific Historical Review 58(4):449-469.

Massa, Ilmo. 1999. "The Development of the Risk Economy in the Circumpolar North," pp. I23-I46 in Ecology and the World-System, Walter L. Goldfrank, David Goodman, and Andrew Szasz, eds. Westport, CT: Greenwood Press.

Meinig, D.W. 1978. "The Continuous Shaping of America: A Prospectus for Geographers and Historians." American Historical Review 83(5): II86-I205.

Meyer, David R. 1983. "Emergence of the American Manufacturing Belt: An Interpretation." Journal of Historical Geography 9(2): I45-I74.

Miranti, Paul J., Jr. I989. “The Mind's Eye of Reform: The ICC's Bureau of Statistics and Accounts and a Vision of Regulation, I887-1940." Business History Review 63(3): 469-509 [independently paginated version from on-line database. http://infotrac.galegroup.com

Moore, Jason W. 2000. "Sugar and the Expansion of the Early Modern World-Economy: Commodity Frontiers, Ecological Transformation, and Industrialization." Review: Fernand Braudel Center xxıII (3):409-433.

Morse, Lewis Kennedy. I9I8. "The Price-Fixing of Copper." Quarterly Journal of Economics 33(I): 7I-106.

Muirragui, Eileen Isabel. I989. "The International Political Economy of Minerals: Copper in the United States and Chile, I945-1986." Ph.D. dissertation, University of Wisconsin.

Newell, Edmund. 1990. "'Copperopolis': The Rise and Fall of the Copper Industry in the Swansea District, I826-I92I." Business History 32(3):75-97.

Newland, D.H. 1904. "Copper." The Mineral Industry 12: 74-I28.

Parsons, A.B. 1933. The Porphyry Coppers. New York: American Institute of Mining and Metallurgical Engineers.

Paul, Rodman W. 1963 [I974]. Mining Frontiers of the Far West, 1848-1880. Albuquerque: University of New Mexico Press.

Pettengill, Robert B. I93I. "The United States Copper Industry and the Tariff." Quarterly Journal of Economics 46(I): I4I-I57.

Pettengill, Robert B. I935. "The United States Foreign Trade in Copper: I790-I932." American Economic Review 25(3): 426-44I.

Pred, Allan. 1965. "Industrialization, Initial Advantage, and American Metropolitan Growth." The Geographical Review 55(2): I58-185.

Richter, F. Ernest. I923. "The Organization of the Copper Market." Harvard Business Review I(2): I96-2II

Richter, F. Ernest. I927. "The Copper-Mining Industry in the United States, I845I925." Quarterly Journal of Economics 4I(2): 236-29I, (4): 684-7I7. 
Richter, F. Ernest. 1931. "The Copper Industry in 1930." Review of Economics and Statistics I3 $(\mathrm{I}): \mathrm{I} 5-\mathrm{I} 8$.

Ripley, William Z. 1923. Railroads: Rates and Regulations. New York: Longmans, Green \& Co.

Robbins, William G. 1994. Colony and Empire: The Capitalist Transformation of the American West. Lawrence: University Press of Kansas.

Rothstein, Morton. 1975. "West Coast Farmers and the Tyranny of Distance: Agriculture on the Fringes of the World Market." Agricultural History 49(r): 272-280.

Rothwell, Richard P., ed. 1893. "Copper." The Mineral Industry I: 107-163.

Rothwell, Richard P., ed. 1897. "Copper." The Mineral Industry 5: 202-230.

Rothwell, Richard P., ed. 1900. "Copper." The Mineral Industry 8: 158-188.

Rubinson, Richard. 1978. "Political Transformation in Germany and the United States." pP. 39-73 in Social Change in the Capitalist World Economy, Barbara Hockey Kaplan, ed. Beverly Hills, CA: Sage Publications.

Schmitz, Christopher. 1986. "The Rise of Big Business in the World Copper Industry, 1870-1930." Economic History Review 2nd ser, 39(3): 392-4IO.

Schmitz, Christopher. 1997. "The Changing Structure of the World Copper Market, 1870-1939." Journal of European Economic History 26(2): 295-330.

Schmitz, Christopher, 2000. "The World Copper Industry: Geology, Mining Techniques and Corporate Growth, 1870-1939." Journal of European Economic History 29(I): 77-105.

Scott, Allen J. 1995. "The Geographic Foundations of Industrial Performance." Competition \& Change I $(\mathrm{I}): 5 \mathrm{I}-66$.

Skowronek, Stephen. 1982. Building a New American State: The Expansion of National Administrative Capacities, 1877-1920. Cambridge: Cambridge University Press.

Strauss, S.D. 1931. "Copper Production Costs in the Americas in 1930." Engineering and Mining Journal I32(2): 68-69.

Su, Tieting. 200I. "World Trade Networks from 1928 to 1938." Journal of WorldSystems Research viI(I): 32-50. http://jwsr.ucr.edu

Thompson, Mark L. 199I. Steamboats \& Sailors of the Great Lakes. Detroit, MI: Wayne State University Press.

United States. Department of War. U.S. Army Corps of Engineers. 1937. Transportation on the Great Lakes. Washington: United States Government Printing Office.

United States. Department of Agriculture. Economic Research Service. 1989. "Revised County Typology for Michigan." http://www.ers.usda.gov/Briefing/ Rurality/Typology/Data/Typ89MI.txt

Walker, George L. I934. "Africa and the New Era in Copper." Engineering and Mining Journal I35(6): 243-247.

Wallerstein, Immanuel. 1991. Unthinking Social Science: The Limits of NineteenthCentury Paradigms. Cambridge: Polity Press.

Warren, Kenneth. 1973. Mineral Resources. New York: John Wiley \& Sons
The Political Economy of Raw Materials Transport

Warriner, G. Keith. I988. "Common Property Rights and Regional Subordination in a Staples Economy: The Rise and Decline of the British Columbia Coastal Fishing Community, I880-1981." Canadian Review of Sociology E Anthropology 25(4): 493-519.

Watkins, Melville H. 1963. "A Staple Theory of Economic Growth." Canadian Journal of Economics and Political Science 29(2): I4I-I58.

Weed, Walter Harvey. I9I2. Geology and Ore Deposits of the Butte District, Montana. United States Geological Survey Professional Paper 74. Washington: United States Government Printing Office.

Weed, Walter Harvey. 1917. "Copper." The Mineral Industry 25: 150-210.

Weed, Walter Harvey. I923. "Copper." The Mineral Industry 3I: 157-205.

Whitten, David O. 1983. The Emergence of Giant Enterprise, 1860-1914: American Commercial Enterprise and Extractive Industries. Westport, CT: Greenwood Press.

Wright, Gavin. I990. "The Origins of American Industrial Success, I879-I940." American Economic Review 80(4): 65I-668. 